\title{
Solving the Batson Paradox:
}

\section{Harmless Error, Jury Representation, and the Sixth Amendment}

\author{
Eric L. Muller ${ }^{\dagger}$
}

\section{INTRODUCTION: THE BATSON PARADOX}

"“[E]very right ... must have a remedy ... ."' Although this idea runs deep through our jurisprudence, it is not strictly true. The challenge is to determine which rights are so important as to require a remedy. Sometimes this is easy, as in the case of Batson v. Kentucky, ${ }^{2}$ which established that the Equal Protection Clause forbids prosecutors from exercising peremptory challenges to strike prospective jurors on account of their race. ${ }^{3}$ Under Batson, a prosecutor is free to exercise peremptory challenges until the defendant objects on the ground that the prosecutor has engaged in intentional discrimination on the basis of race. ${ }^{4}$ If the court finds that the defendant has made a prima facie showing of racial discrimination, the burden then shifts to the prosecutor to present a race-neutral explanation for the strike. If the court discredits that explanation, or if the defendant can show the race-neutral explanation to be pretextual, then a Batson violation has occurred. ${ }^{6}$

$\doteqdot$ Assistant Professor. University of Wyoming College of Law A.B. Brown Cnuversty, J D. Yale University.

My thanks to Robert Burt, Jonathan Entin. Mare Garber. Randy Jonakaut. Andy Leıpold. Nancy Marder, Bill Marshall, Glenn Moramarco. Brad Saxion. Joci Selıg. Gary Simson. and Harold Taw for their very helpful comments on drafts of this Article: to Melissi Larkun-Hughes for her careful research assistance; and to the Hopper Research Fund for its generous financial support

1. Marbury v. Madison, 5 U.S. (I Cranch) 137. 163 (1803) (quotung 3 Williss BLACKstonE. COMMENTARIES *109).

2. 476 U.S. 79 (1986).

3. An earlier case, Swain v. Alabama, 380 U.S. 202 (1965). had established the same general prunciple but insisted on a pattern of discrimination in case after case as proof of an equal protection volation $l d$ at 224. Batson ovemuled this aspect of Sirain, allowing proof of a proma facie case of impermissible discrimination from the facts of jury selection at a single trial Batson. 476 L'S at 93-96

4. See Batson, 476 U.S. at $96-97$.

5. See id. at $97-98$.

6. See id:; Williams v. Groose, 77 F.3d 259. 261 (8th Cir 1996) (allowing defendant to shou that prosecutor's race-neutral reason is pretextual): of. Purkell v. Elem. $115 \mathrm{~S} \mathrm{Cl} 1769$ (1995) (per cunam) (holding that race-neutral explanation need not be persuasive, or even plausible. to advance Barson analysis to ultimate question of purposeful discnmination). 
Batson's timing alone suggests that it announced an important principle. The case was decided in 1986-a time when the Court was not particularly friendly to the claims of criminal defendants. It overruled Swain v. Alabama, a case decided in 1965, when the Court's concerns for protecting criminal defendants' rights, and for combatting racial discrimination, were at their apex. Even more remarkably, in the years since Batson-years in which the Court has grown no friendlier to defendants' claims ${ }^{8}$ - the Court has clung tenaciously to the Batson norm, continually expanding its scope. ${ }^{9}$ Obviously, the Court believes that it is on to something important in Batson and its progeny.

If every important right has a remedy, then surely there ought to be a remedy for a Batson violation. ${ }^{10}$ Undoubtedly there is-at least at the trial level. Upon finding a violation of Batson, the trial court may order that the improperly challenged jurors remain seated, or it may dismiss the jurors

7. 380 U.S. 202 (1965).

8. The Rehnquist Court has revealed its lack of enthusiasm for the claims of criminal defendants most clearly in its dramatic narrowing of the writ of habeas corpus. See, e.g., Herrera v. Collins, 506 U.S. 390 (1993) (rejecting claim of actual innocence based on newly discovered evidence as ground for federal habeas relief); Coleman v. Thompson, 501 U.S. 722 (1991) (raising standard habeas petitioner must meet to obtain federal court review of claim procedurally defaulted in state court); McCleskey v. Zant, 499 U.S. 467 (1991) (raising standard habeas petitioner must meet to obtain federal court review of claim raised in second or successive federal habeas petition); Teague v. Lane, 489 U.S. 288 (1989) (forbidding development of new rules of constitutional criminal procedure in federal habeas cases). For an excellent description of the recent revolution in habeas corpus law, see Larry W. Yackle, The Habeas Hagioscope, 66 S. CAL. L. REv. 2331 (1993).

The Rehnquist Court's antipathy to the claims of criminal defendants has surfaced outside the habeas context as well. See, e.g., United States v. Williams, 504 U.S. 36 (1992) (holding federal prosecutor has no duty to disclose exculpatory information in his possession to grand juries considering criminal charges); Harmelin v. Michigan, 501 U.S. 957 (1991) (finding automatic imposition of mandatory sentence of life in prison without possibility of parole for possessing more than 650 grams of cocaine does not constitutc cruel and unusual punishment within meaning of Eighth Amendment); Payne v. Tennessee, 501 U.S. 808 (1991) (allowing capital sentencing juries to consider victim impact statements); Stanford v. Kentucky, 492 U.S. 361 (1989) (allowing death penalty for murderer who was 16 years old when crime was committed); Penry v. Lynaugh, 492 U.S. 302 (1989) (finding execution of mentally retarded people convicted of capital offenses does not violate Eighth Amendment). But cf. Craig M. Bradley, Criminal Procedure in the Rehnquist Court: Has the Rehnquisition Begun?, 62 IND. L.J. 273, 275 (1987) (noting that review of Chicf Justice Rehnquist's opinions "suggests that the future of criminal procedure, even in a Court in which the views of Justice Rehnquist held greater sway than they do now, would not differ as radically from current law as his critics suggest"). See generally Barry Friedman, Habeas and Hubris, 45 VAND. L. REv. 797, 821 (1992) ("[I]t is evident that this Court has a great hostility to the rights of criminal defendants.").

9. See J.E.B. v. Alabama ex rel. T.B., 114 S. Ct. 1419 (1994) (extending Batson to gender-based peremptory challenges); Georgia v. McCollum, 505 U.S. 42 (1992) (extending Batson to peremptory challenges by defense counsel in criminal cases); Edmonson v. Leesville Concrete Co., 500 U.S.614 (1991) (extending Batson to peremptory challenges by private litigants in civil cases); Powers v. Ohio, 499 U.S. 400 (1991) (extending Batson to objection by white defendant to exclusion of black jurors).

10. In this Article, I frequently refer to a "Batson violation" or a "Batson error" in a generic sense. I do not mean a scenario identical to the one in the Batson case itself (a prosecutor's discriminatory strike of a minority juror of the same race as the defendant), but any of the scenarios to which the Court has extended the Batson norm-situations where the juror and defendant are not of the same race, situations where the party engaging in discrimination is the defendant, and situations where an attorney strikes jurors on account of gender rather than race. 
already seated and begin the process of jury selection anew." But what if the trial court errs, finding no Batson violation where there actually was one? ${ }^{12}$ What is the appropriate remedy on direct appeal? ${ }^{13}$

In keeping with its view that Batson error is serious business, the Supreme Court has assumed, but never formally ruled, that the appropriate appellate remedy is automatic reversal of the conviction. That is, the Court has never suggested that a conviction tainted by Batson error might nonetheless be affirmed if, for example, the evidence against the defendant were overwhelming; it has instead simply reversed convictions outright without performing harmless error analysis. ${ }^{14}$

Because the Court has never directly addressed the question of remedy, its reasons for choosing automatic reversal over harmless error analysis are not clear. Perhaps the Court agrees with Susan Herman's instinct that "harmless error analysis would seem irrelevant"15 on Batson appeals. The Batson "right" is actually a package of equal protection rights: rights of the defendant to a fair trial free of the stigma of racial prejudice, and rights of prospective jurors both to be free of that stigma and to participate fully in the criminal justice system. Especially where the injury is to the jurors' rights, the Cour may think that it would be beside the point to examine the impact of that injury on the verdict. Where it is the defendant who is injured by the discrimination, the Court may believe that the effects of the injury are so diffuse as to make harmless error analysis impossible.

The Court may even be right: Batson error may indeed be ill-suited to appellate review for impact on the verdict. But this does not necessarily mean,

\section{As the Court noted in Batson:}

[W] express no view on whether it is more appropnate in a particular case, upon a tinding of discrimination against black jurors, for the trial coun to discharge the venire and select a new jury from a panel not previously associated with the case. or to disallow the disenminatory challenges and resume selection with the improperly challenged jurors reinstated on the venire Batson, 476 U.S. at 100 n.24 (citation omitted). Some courts have determined that reınstating the wrongly challenged jurors is an appropriate remedy. See. e.g. State ex rel. Curny v. Bowman. 885 S W 2d 421 . 424-25 (Tex. Crim. App. 1993) (en banc) (approving practice of retauning improperly challenged jurors) Other courts have deemed dismissing the entire panel to be the "belter practice" Sec, eg. State $v$ McCollum, 433 S.E.2d 144, 159 (N.C. 1993).

Charles Ogletree has argued that the alternative of dismissing the enture array and starting jury selection anew is insufficiently punitive. See Charles J. Ogletree. Just Sa, No' A Proposal to Elıminate Racially Discriminarony Uses of Peremptory Challenges, 31 AM. CRIM L REV 1099. 1116 (1991) On the other hand. Alber Alschuler has argued that neither of the Batson Court's iwo altematuves is satisfactory. See Albert W. Alschuler, The Supreme Court and the Junn. Voir Dire. Peremptory Challenges. and the Review of Jury Verdicts, 56 U. CHI. L. REV, 153, 177-79 (1989).

12. The inverse question-"what if the trial court errs, finding a Batson violation where there actually was not one?"-is a distinct issue that is outside the scope of this Artucle. For an explanation of why this issue is distinct from the one I address in this Article. sec infra note 294.

13. In this Article, I address only the question of the appropnate remedy for Batson crror on direct appeal. I do not consider the question of whether or when a remedy should be avalable on collateral review.

14. See infra note 148 .

15. Susan N. Herman. Why the Court Loves Batson Representation-Reinforcement, Colorblindness. and the Jury, 67 TUL. L. REV. 1807, 1831 n.98 (1993). 
as the Court seems to assume, that the appropriate remedy for a Batson violation is a rule of automatic reversal. For as the Supreme Court (albeit a very different majority from the one that produced Batson) has made clear in recent years, the remedy of appellate reversal exists for one purpose only-to protect the reliability of the jury's "factual finding" on the question of the defendant's guilt or innocence. ${ }^{16}$ If Batson error does not undermine the reliability of verdicts, then appellate courts should affirm, not reverse, convictions.

Herein lies part of the paradox of Batson. For all of the Court's heated rhetoric about the evils of discrimination in the exercise of peremptory challenges, the Court has firmly rejected the idea that a juror's race or gender has any bearing on how that juror will view the evidence in a case or vote on the question of guilt or innocence. By taking this position, the Court has defined Batson violations in a way that absolutely forecloses any possibility that such violations affect the reliability of the verdict. Batson violations do other bad things, of course: they stigmatize litigants and jurors, and wrongly prevent jurors from participating in the justice system. These are serious equal protection harms, but they have nothing to do with the reliability of verdicts. Thus the Court has articulated a package of rights which, in logic, require no appellate remedy.

That, however, is not the whole paradox. For there are indeed Justices on the Court who should see harm in a Batson scenario-not just any kind of harm, but the kind that makes verdicts unreliable and warrants reversal on appeal. These are Justices who embrace the idea that a juror's race or gender is at least a minimally rational predictor of that juror's likely perspective on certain issues in a criminal trial. But these are also the Justices who have opposed and criticized the entire Batson enterprise and who see no error of any kind in a Batson situation. This, then, is the full paradox of Batson: the Justices who would find harm in a Batson violation cannot; the Justices who can find harm in a Batson violation will not.

In this Article, I will explain and resolve this paradox about the true nature of the harm that Batson error causes to criminal verdicts. To do so, I will first show how the paradox arises-how it is that the Court's proponents of the Batson norm have managed the incoherent task of creating a type of error that is, by definition, harmless in every case. I do this in Parts II through IV. In the balance of the Article, I show that the resolution of the paradox emerges not from curing the incoherence in the views of Batson's proponents, but from resolving the far deeper incoherence in the views of the Justices who have opposed and criticized the Batson norm. I argue that the discriminatory use of peremptory challenges does indeed undermine the reliability of criminal verdicts and should trigger a rule of automatic reversal on appeal, but not

16. See infra Part III. 
because it violates any value in the Equal Protection Clause. ${ }^{17}$ Rather, this sort of discrimination violates the Sixth Amendment's guarantee of a jury that represents the community. ${ }^{18}$ I conclude that the Court must deploy the Batson rule to protect the Sixth Amendment value of community representation on the jury, and that the Court should therefore overrule its holding to the contrary in Holland v. Illinois. ${ }^{19}$

\section{DO RACE AND GENDER SUGGeST VIEWPOINT?}

THE LIFE, DEATH, AND LIFE OF THE "THEORY OF DIFFERENCE" IN THE SUPREME COURT

In the prosecutor's office where I once worked, a supervisor always counseled new attorneys litigating drug cases to use a peremptory challenge to remove any prospective juror who came to court with a coffee mug or shoulder bag bearing the emblem of the local public broadcasting station. He reasoned that people get such merchandise in only one way-by donating money to public broadcasting. Anyone who would give money to public broadcasting. he argued, was too much of a mushy-headed liberal to give the government's case a favorable hearing.

Such rough inferences drive our system of peremptory challenges. The supervisor knew that the inference was ridiculously overbroad, but his experience told him that it was not flatly irrational. He saw enough of a correlation between a juror's television and radio preferences and her likely viewpoint on drug enforcement to make the peremptory strike worthwhile.

For many years, the Supreme Court has struggled with the similar question of whether it is rational for an attorney to draw inferences about viewpoint from a prospective juror's race or gender. This inquiry has been just one piece of a larger problem that has plagued the Court: Is it ever rational, in any context, to attribute distinctive views or beliefs to a segment of the community defined by an immutable characteristic like race or gender? At times the Court seems to have thought so. For example, in Metro Broadcasting, Inc. $v$. $F C C,{ }^{20}$ the Court approved a system of preferential licensing for minorityowned broadcasting companies on the theory that such a system would enhance broadcast diversity. The Court deemed it "a legitimate inference . . . to draw that as more minorities gain ownership and policymaking roles in the

17. See infra text accompanying note 178 .

18. I do not address the question of whether jury discrimination in cril cases violates the jury tnal guarantee in the Seventh Amendment. See U.S. CONST amend Vil

19. 493 U.S. 474 (1990).

20. 497 U.S. 547 (1990), overruled by Adarand Consirs. Inc 、 Pena. $115 \mathrm{~S}$ Ci 2097 11995) The Adarand opinion overtuled Metro Broadcasting on the level of judicial senutiny applitable to federal affirmative action plans; Adarand did not explicitly call into question Merro Broadeasting's broadeast diversity theory. 
media, varying perspectives will be more fairly represented on the airwaves."21 The Metro Broadcasting Court found it rational for Congress to attribute certain broad views and preferences, even if not a "cohesive, collective viewpoint,"22 to minority groups.

On the other hand, the Court has often scolded parties for drawing precisely this inference. In Miller $v$. Johnson, ${ }^{23}$ the Court held that when a state draws voting district lines for the predominant purpose of turning racial minorities into district majorities, that plan violates the Equal Protection Clause of the Fourteenth Amendment regardless of the district's geographical shape. ${ }^{24}$ According to the Court, mapping districts in this way is inevitably infected with the "offensive and demeaning assumption that voters of a particular race, because of their race, 'think alike, share the same political interests, and will prefer the same candidates at the polls." 25 The very notion of using race to predict viewpoint was, for the Miller Court, irrational stereotyping. ${ }^{26}$

In one area, however, the Court has historically been unequivocal in embracing what might be called the "theory of difference"27-that is, the

21. Metro Broadcasting, 497 U.S. at 582. Justice Powell made a similar argument on the benefits of racial and other sorts of diversity on university and medical school campuses in Regents of Univ. of California v. Bakke:

The atmosphere of "speculation, experiment, and creation"--so essential to the quality of higher education-is widely believed to be promoted by a diverse student body.

... An otherwise qualified medical student with a particular background-whether it be ethnic, geographic, culturally advantaged or disadvantaged-may bring to a professional school of medicine experiences, outlooks, and ideas that enrich the training of its student body and better equip its graduates to render with understanding their vital service to humanity.

Bakke, 438 U.S. 265, 312-14 (1978) (opinion of Powell, J.).

22. Metro Broadcasting, 497 U.S. at 582.

23. 115 S. Ct. 2475 (1995).

24. See id. at 2494.

25. Id. at 2486 (quoting Shaw v. Reno, 113 S. Ct. 2816, 2827 (1993)).

26. The Court took this view even while engaging in some of that "irrational" stereotyping itself. The plaintiffs in Miller were white voters from the district that had been drawn to create a black majority. See id. at 2485 . To establish their standing to challenge the districting plan, the plaintiffs had to show that they had suffered injury. See id.; see also Lujan v. Defenders of Wildlife, 504 U.S. 555, 560 (1992) (summarizing standards for constitutional requirement of "injury in fact"). As Justice Stevens pointed out in his Miller dissent, the only harm that these plaintiffs suffered was the "representational harm" identified in Shaw, $113 \mathrm{~S}$. Ct. at 2827; namely, the harm that arises in a racially gerrymandered district when the elected officials come to believe that their duty is to represent only the members of the dominant group, rather than their entire constituency. See Miller, 115 S. Ct. at 2497 (Stevens, J., dissenting). Ironically, this theory of standing depends on precisely the same inference about the viewpoint-predictive value of race that the Miller Court condemns. That is, it depends on the simple idea-openly scorned in Justice Kennedy's opinion for the Court-_that individuals of the same race share a single political interest." Id. at 2487 . Thus, in the very same case, the Court both implicitly endorsed and explicitly condemned the idea that race predicts perspective.

27. This theory has gained currency in recent scholarship, particularly that of some critical race and feminist theorists. See T. Alexander Aleinikoff, A Case for Race-Conscionsness, 91 ColuM. L. REv. 1060, 1066, 1084 (1991) (arguing that "race may have an influence on how members of society understand their worlds and each other," and that "the views of subordinated groups on the extent and nature of subordination are likely to differ from those of majority groups"); Darryl K. Brown, The Role of Race in Jury Impartiality and Venue Transfers, 53 MD. L. REV. 107, 149-50 (1994) (summarizing "difference" scholarship and arguing that "[r]ace is a determinative prism through which people interpret social events 
theory that jurors' race and gender are at least minimally rational predictors ${ }^{23}$ of their perspective. ${ }^{29}$ This area is the law of grand and petit jury composition. Prior to Batson, the theory of difference was an important premise of the Court's work in making sure that grand and petit juries are truly representative of discrete segments of the community.

The Court first expressed this premise openly in Ballard $v$. United States, ${ }^{30}$ where it exercised its supervisory power over the administration of justice in the federal courts ${ }^{31}$ to require the inclusion of women in the venires from which grand and petit juries were selected. While rejecting the simplistic notion that men and women act predictably as rigid classes, ${ }^{32}$ the Court readily embraced the subtler idea that "the two sexes are not fungible; a community made up exclusively of one is different from a community composed of both." "[A] flavor, a distinct quality is lost," the Count insisted, "if either sex is excluded" from juries. ${ }^{34}$

The Court reaffirmed its commitment to this theory of difference in Taylor v. Louisiana, ${ }^{35}$ when it expanded Ballard from a supervisory to a constitutional rule. Taylor asked whether the Sixth Amendment's guarantee of

and understand both human behavior and the law and through wheh they apply the latter to the former"). Ann E. Freedman, Sex Equaling. Sex Differences, and the Supreme Courn, 92 Y+LE LJ 913.965 (1983) (arguing "that women have distinctive perspectuves that must play an important role in socia! transformation"); Mari J. Matsuda, Looking to the Bollom: Crincal Leg'al Simdies and Reparanons. 22 HARV. C.R.-C.L. L. REV. 323, 323-35, 360 (1987) (urging reform of Critical Legal Studies movement to adopt more unambiguously distinctive perspective. or "normalise intuitions|.] of those on the bottom")

28. By using the word "predictor." I do not mean to suggest that race or gender "predicts" a juror's perspective in the same way that, say, a drop in barometnc pressure "predicts" a nasty tum in the weather I am referring instead to something more vague and less confident, a suspicion or hunch that an attorney thinks is more likely tue than not and one that the attorney therefore comfortably relies upon when exercising peremptory challenges.

29. When I speak of a juror"s "perspectuve" or "vieupoint" in this Aricle. I mean a difiuse experiential filter through which a juror perceives the evidence and the events at tnal See Mark Cammack. In Search of the Post-Posinvist Jun. 70 IND. L.J. 405.416 (1995) ("All expenence is mediated by preexisting knowledge structures, constellations of assumptions, interests, and purposes that filter and organize perception as it occurs."). I do not mean a conscious, hard-and-fast commiment to specitic outcome-determinative beliefs. This sor of commiment is the stuff of true "bias." mahing a juror properly challengeable for cause.

30. 329 U.S. 187 (1946).

31. See generally McNabb v. United States. 318 U S 332. 340-\$1 (1943) (desenbing Supreme Court's supervisory power).

32. See Ballard. 329 U.S. at 193.

33. Id.

34. Id. at 194. Earlier in that same Term, the Coun had flirted with the more radical idea that "wage earners," as a group, can rationally be presumed to share a disuncuve vicwpoint in Thicl . Southem Pac Co., 328 U.S. 217 (1946), the Cour exercised its supervisory power to condemn the practice of excluding all laborers paid a daily wage from jury service. See id al 225 The disinct coun had rested its decision squarely on the idea that wage earners, as a group. shared a common perspectuse See ad at 220 The Supreme Coun, however. did not analyze the problem in quite this uay Instead, it condemned the exclusion of wage eamers as inconsistent with "the proper rules and pnneiples of jury selection " $1 d$ at 221 While suggesting that the exclusion of wage eamers would do "volence to the democratic nature of the jury system" and "breathe life into any latent tendencies to estublish the jun as the instrument of the economically and socially privileged," id. at 223-24. the Coun nowhere suggested that the exclusion would strip the jury of a discrete and identıfiable perspectuve.

35. 419 U.S. 522 (1975). 
an impartial jury prohibited a system in which women could not be called for jury service unless they first filed a written declaration that they wished to serve. ${ }^{36}$ Holding that "the selection of a petit jury from a representative cross section of the community is an essential component of the Sixth Amendment right to a jury trial,"37 the Court struck down Louisiana's "opt-in" system for women. ${ }^{38}$ The Court endorsed Ballard's rejection of the "view that an allmale panel drawn from various groups in the community would be as truly representative as if women were included." 39 Quoting Ballard for the proposition that " a distinct quality is lost if either sex is excluded," "40 the Court held that the core function of the jury is eviscerated "if the jury pool is made up of only special segments of the populace or if large, distinctive groups are excluded from the pool.",1

The Court has also embraced the theory of difference in the context of racial exclusion. In Peters $v$. Kiff, ${ }^{42}$ the Court granted a writ of habeas corpus to a defendant who had been indicted for, and convicted of, burglary by grand and petit juries from which blacks had been systematically excluded. The novelty in Peters was that the defendant was white. Seizing on this, the State argued that he had suffered no harm by the exclusion of blacks from his grand and petit juries. The Court rejected this argument. ${ }^{43}$ Writing for himself and two other Justices, Justice Marshall concluded that the Due Process Clause of the Fourteenth Amendment ${ }^{44}$ forbade a state from submitting a defendant of any race to a trial by a jury from which blacks had been systematically excluded. To the State's argument that the white defendant had not been harmed by this exclusion, Justice Marshall responded that "the exclusion from jury service of a substantial and identifiable class of citizens has a potential impact that is too subtle and too pervasive to admit of confinement to

36. See id. at 523 .

37. Id. at 528 .

38. See id. at 533.

39. Id. at 531 .

40. Id. at 532 (quoting Ballard v. United States, 329 U.S. 187, 194 (1946)).

41. Id. at 530 .

42. 407 U.S. 493 (1972).

43. The Peters case produced three groups of three Justices. Justices Douglas, Stewart, and Marshall voted to grant the writ on a due process theory. See id. at 501-05. Justices Brennan, White, and Powell concurred in the judgment, preferring to grant the writ on the theory that the racial exclusion violated policy embodied in a federal statute. See id. at 505-07. Chief Justice Burger and Justices Blackmun and Rehnquist dissented. See id. at 507-13. While the case produced no majority or plurality opinion, only three of the Justices explicitly disagreed with Justice Marshall's comments about the nature of the harm caused by the exclusion of black jurors. See id. at 510-11.

For a thorough analysis of the various opinions in Peters v. Kiff-from a person who was involved in the formulation of Justice Marshall's opinion-see Barbara D. Underwood, Ending Race Discrimination in Jury Selection: Whose Right Is lt, Anyway?, 92 CoLuM. L. REv. 725, 739-42 (1992).

44. The "impartial jury" requirement of the Sixth Amendment was not available as a basis for decision because the trial in Peters had preceded Duncan v. Louisiana, 391 U.S. 145 (1968) (applying Sixth Amendment right to petit jury to states through Fourteenth Amendment), and Duncan did not apply retroactively, see DeStefano v. Woods, 392 U.S. 631 (1968). See Peters, 407 U.S. at 496. Justice Marshall relied instead on the due process notion that a tribunal must be impartial. See id. at 501-02. 
particular issues or particular cases." ${ }^{.45}$ More fundamentally, Justice Marshall refused to assume that the exclusion of black jurors has an impact only on cases touching explicitly on race:

When any large and identifiable segment of the community is excluded from jury service, the effect is to remove from the jury room qualities of human nature and varieties of human experience, the range of which is unknown and perhaps unknowable. It is not necessary to assume that the excluded group will consistently vote as a class in order to conclude, as we do, that its exclusion deprives the jury of a perspective on human events that may have unsuspected importance in any case that may be presented. ${ }^{36}$

Thus, while race may not offer hard and fast predictions on precise voting patterns in specific cases, it does produce "a perspective on human events" that cannot be excluded without subverting the representativeness of the jury.

The Court's pre-Batson cases on grand and petit jury discrimination reflected a commitment to the view that one might rationally glean some hint of a person's perspective from his or her race or gender. Yet in 1986, when the Court began to grapple with the discriminatory use of the peremptory challenge, it had a change of hear. ${ }^{47}$ Race and gender became not just impermissible but flatly irrational predictors of juror perspective.

The Court was initially somewhat tentative on the subject. In Batson, ${ }^{45}$ the first of the Court's cases limiting the use of the peremptory challenge in individual trials, ${ }^{49}$ the Court announced the rule that the Equal Protection Clause forbids a prosecutor from using peremptory challenges to strike prospective jurors solely on account of their race. ${ }^{50}$ The Court seemed to exclude the possibility that a prosecutor might have even the most minimally rational reason for wanting to excuse a juror from serving in any case because of his race: "A person's race simply 'is unrelated to his fitness as a juror."'s1 The Court did not say exactly what it meant by "unrelated"; it might have meant that race was unrelated to a juror's performance as a matter of law, or it might have meant that race was unrelated to a juror's performance as a matter of fact. The Court's proposition about "unrelatedness" was, however,

45. Peters, 407 U.S. at 503.

46. Id. at 503-04. In suppon of this proposition. Jusuce Marshall ctied Jusuce Douglas's words about the effect of gender exclusion from Ballard. See id. at 504 n.12 (quoung Ballard 、 United Statcs. 329 C' S 187, 193-94 (1946)).

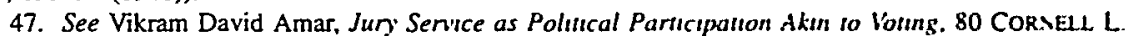
REV. 203, 210 (1995) (noting "great deal of tenston" between Court's older and most recent cases on issue of whether group affiliation predicts juror perspective).

48. 476 U.S. 79 (1986).

49. See supra note 3 .

50. See Batson, 476 U.S. at 89.

51. Id. at 87 (quoting Thiel v. Southem Pac. Co., 328 U.S. 217. 227 (1946) (Frankfurter. J. dissenting)). 
a quote from Justice Frankfurter's dissenting opinion in Thiel $v$. Southern Pacific $\mathrm{Co}^{52}$ In that opinion, Frankfurter argued quite plainly that the exclusion of the group of "daily wage earners" from federal juries in California could have no impact on those juries' deliberations, since wage earners, as a matter of fact, do not have "a different social outlook, . . . a different sense of justice, ... [or] a different conception of a juror's responsibility than their fellow workers paid by the week." 53 Thus, while the Batson Court did not directly address the predictive value of race on juror performance, it indirectly suggested that there was none. ${ }^{54}$

Just a few years later, however, the Court stated this point more clearly. In Edmonson v. Leesville Concrete Co. ${ }^{55}$ the Court explained that an attorney exercising a peremptory challenge on the basis of race might have two conceivable reasons for doing so: either "open hostility" or "some hidden and unarticulated fear." ${ }^{\text {} 56}$ Both, the Court stated, are irrational: the only "rational way" for the attorney to proceed would be "without the use of classifications based on ancestry or skin color." ${ }^{\text {57 }}$ In Edmonson, the Court said more clearly what it had hinted at in Batson: Classifications based on race are not just impermissible as a matter of law but are also irrational as a matter of fact. ${ }^{58}$

By the time the Court decided J.E.B. v. Alabama ex rel. T.B. ${ }^{59}$ it was not merely announcing that race and gender do not rationally predict juror perspective, but preaching that view with a vengeance. J.E.B. was an action initiated by the State of Alabama for paternity and child support. At trial, the State and the defendant played the common game of dueling peremptories: ${ }^{60}$ the State used nine of its ten challenges to remove men from the jury; the defendant used all but one of his to remove women. ${ }^{61}$ When the State

52. 328 U.S. 217, 227 (1946) (Frankfurter, J., dissenting).

53. Id. at 230 (Frankfurter, J., dissenting); see also id. (Frankfurter, J., dissenting) ('The exclusion of the daily wage earners does not remove a group who would, in the language of Mr. Justice Holmes, "act otherwise than those who are drawn would act.") (quoting Rawlins v. Georgia, 201 U.S. 638, 640 (1906)).

54. In the Court's next case addressing Batson, Powers v. Ohio, 499 U.S. 400 (1991), the Court said nothing more about the issue. It merely cited Batson for the proposition that juror race "simply "is unrelated"' to juror fitness. Id. at 410 (quoting Batson, 476 U.S. at 87).

55. 500 U.S. 614 (1991).

56. Id. at 631 .

57. Id.

58. I am not suggesting that the Court's rejection of the theory of difference was its only, or even its primary, reason for holding race-based peremptory challenges to be impermissible. The Court has stated a number of reasons why such challenges violate the law: they deny the equal protection rights of the challenged jurors, harm the community, and compromise the integrity of the justice system. See infra Part IV. Under prevailing law, however, see infra Parts III-IV, these reasons have little to do with the question at the heart of this Article: What harm does Batson error pose to the reliability of verdicts?

59. 114 S. Ct. 1419 (1994).

60. Cf. Edmonson, 500 U.S. at $642-43$ (O'Connor, J., dissenting) ("In a civil trial, the attorneys for each side ... . use their peremptory strikes in direct opposition to one another, and for precisely contrary ends."); Gray v. Mississippi, 481 U.S. 648, 679 (1987) (Scalia, J., dissenting) ("Since defendants presumably use their peremptory challenges in the opposite fashion, the State's action simply does not result in juries 'deliberately tipped toward' conviction." (citation omitted)).

61. See J.E.B., 114 S. Ct. at 1422. 
defended its gender-based use of peremptories on the theory that men and women might rationally be presumed to have different views on issues relating to paternity and child support, the Court responded with thinly veiled contempt and hostility. The Court belittled the State's "quasi-empirical claim," noting that " $[t]$ he majority of studies suggest that gender plays no identifiable role in jurors' attitudes." 62 The Court criticized the State for "offer[ing] virtually no support for the conclusion that gender alone is an accurate predictor of juror's [sic] attitudes," 63 but suggested that such a stereotype would be far too gross even if the State could have "conjured up" some statistical support for it." The State's argument about gender-based differences in perspective contained, at very most, only a "shred" of truth" that did not suppon the exercise of a peremptory challenge. Thus, in cases forbidding discriminatory peremptory strikes, the Court has, with increasing firmness and stridency, rejected the very theory of difference that it had embraced for many years in its earlier jury discrimination cases.

This is not to say, however, that the theory of difference is dead. In fact, quite the opposite is true: The theory of difference lives on in the opinions of the Justices who have opposed the Batson rule and its extension. In Batson itself, Chief Justice Burger warmly embraced the theory in his dissenting opinion. He quoted Professor Barbara Babcock for the proposition that "“[c]ommon human experience, common sense, psychosociological studies, and public opinion polls tell us that it is likely that certain classes of people statistically have predispositions that would make them inappropriate jurors for particular kinds of cases." race were admirable for "“allow[ing] the covert expression of what we dare not say but know is true more often than not." ${ }^{67}$ Justice Rehnquist said much the same thing in his Batson dissent. ${ }^{68}$

62. Id. at 1426 n.9.

63. Id. at 1427. This was an ironic crucism for the Count to make The best suppon avalable for the State's claim was the Cour's own words in Ballard v: Untied Stares. 329 U S 187 (1946). see supra text accompanying notes 30-34, which the J.E.B. Court itself quoted exicnsively and approvingly See $J E B$. $114 \mathrm{~S}$. Ct. at 1424. The J.E.B. majority's vacillation on the validity of the Court's carlier insight in Ballard seems to confirm Justice Scalia's assertion that the Court's J.E.B opinion is "in opposition to its earlier Sixth Amendment 'fair-cross-section' cases." Id. at 1436 (Scalıa, J. dissenung)

64. J.E.B., 114 S. Ct. at 1427 n.11.

65. Id.

66. Batson v. Kentucky, 476 U.S. 79. 121 (1986) (Burger, C.J . dissentıng) (quoung Barbara Babcock. Voir Dire: Preserving "Its Wonderful Power". 27 STAN. L. REv. 545. 553-54 (1975)) The Chief Justice makes a similar point when he suggests that "'each race may have its own special concerns, or even may tend to favor its own ...." /d. at 123 (Burger. C.J., dissentung) (quoung United States 、 Leslie. $783 \mathrm{~F} 2 \mathrm{~d}$ 541, 554 (5th Cir. 1986) (en banc)).

67. Id. at 121 (Burger, C.J., dissenting) (quoung Babcoch. supra note 66. at 554)

68. Justice Rehnquist explained:

The use of group affiliations, such as age. race. or occupation. as a "proxy" for potential juror partiality, based on the assumption or belief that members of one group are more lihely to favor defendants who belong to the same group, has long been accepted as a legulumate basis for the State's exercise of peremptory challenges. . . Indoed. . . the use of such "provies" by both the State and the defendant may be extremely useful in elımınatung from the jury persons who 
Over time, just as Batson's proponents grew blunter in asserting that group affiliation predicts nothing about juror perspective, Batson's opponents grew more committed to the opposite assertion. For example, in his dissenting opinion in Powers v. Ohio, ${ }^{69}$ Justice Scalia described the notion that "all groups tend to have particular sympathies and hostilities" as an "undeniable reality." ${ }^{70}$ Justices O'Connor and Thomas stated similar views in their opinions in Georgia v. McCollum. ${ }^{71}$ By the time of J.E.B., the dissenters were openly and stridently endorsing the theory of difference. Chief Justice Rehnquist stated categorically that "[t]he two sexes differ, both biologically and, to a diminishing extent, in experience." "It is not merely 'stereotyping," he continued, "to say that these differences may produce a difference in outlook which is brought to the jury room." "J3 Justice Scalia, joined by the Chief Justice and Justice Thomas, mocked Justice Blackmun's majority opinion for its "fervent defense of the proposition il n'y a pas de différence entre les hommes et les femmes." "74 Justice O'Connor said it most simply of all: "We know that like race, gender matters."75

Batson and its progeny have thus divided the Justices into two distinct camps on the question of whether group affiliation is a rational proxy for perspective. ${ }^{76}$ On the one hand, Batson's champions doggedly deny that an

might be biased in one way or another.

Id. at 138-39 (Rehnquist, J., dissenting) (citations omitted).

69. 499 U.S. 400 (1991).

70. Id. at 424 (Scalia, J., dissenting).

71. 505 U.S. 42, 68 (1992) (O'Connor, J., dissenting) ("It is by now clear that conscious and unconscious racism can affect the way white jurors perceive minority defendants ...."); see id. at 60 (Thomas, J., concurring in judgment) (agreeing with Justice O'Connor); see also Brown v. North Carolina, 479 U.S. 940, 941 (1986) (O'Connor, J., concurring in denial of certiorari) ("We ought not delude ourselves that the deep faith that race should never be relevant has completely triumphed over the painful social reality that, sometimes, it may be.").

72. J.E.B. v. Alabama ex rel. T.B., 114 S. Ct. 1419, 1435 (1994) (Rehnquist, C.J., dissenting).

73. Id. (Rehnquist, C.J., dissenting).

74. Id. at 1436 (Scalia, J., dissenting). The French expression means "there is no difference between men and women."

75. Id. at 1432 (O'Connor, J., concurring). Justice $O^{\prime}$ Connor is perhaps not a true dissenter from the Batson line of cases; for example, she concurred in the Court's opinion in Batson itself, and concurred in $J . E . B$. because she felt that the nation's commitment to nondiscrimination in jury selection outweighed the litigants' desires to remove certain classes of jurors who might rationally be presumed to harbor defined views. See id. (O'Connor, J., concurring). Still, of all of the Justices who have endorsed Batson and its extension to at least some new contexts, Justice $O^{\prime}$ Connor has been the most vocal in expressing reservations about the rule of Batson and its impact on the institution of the peremptory challenge. See $i d$. at 1431 (O'Connor, J., concurring) ("Because I believe the peremptory remains an important litigator's tool and a fundamental part of the process of selecting impartial juries, our increasing limitation of it gives me pause."); Brown, 479 U.S. at $941-42$ (O'Connor, J., concurring in denial of certiorari) (emphasizing that Batson limitation on unfettered exercise of peremptories ought to be limited to race-based peremptorics).

76. As some have suggested, it seems odd to ask whether group affiliation is a rational proxy for perspective for the purposes of the equal protection analysis in Batson. Equal protection law demands more than a rational basis of a state actor who would intentionally disadvantage a person on account of race or gender. See Miller v. Johnson, 115 S. Ct. 2475, 2490 (1995) (requiring State to present "compelling" interest to defend racial classification successfully); Craig v. Boren, 429 U.S. 190, 197 (1976) (requiring State to present "important" interest to defend gender classification successfully). Thus the normative philosophy of the Equal Protection Clause may be at war with even a minimally rational race- or genderbased peremptory challenge. See Batson v. Kentucky, 476 U.S. 79. 123-25 (1986) (Burger, C.J.. 
attorney may rationally infer anything about a juror's viewpoint from his or her race or gender. On the other hand, Batson's critics openly embrace the idea-grounded in decades of precedent in jury discrimination cases ${ }^{77}$ - that attorneys may rationally infer that members of discrete groups bring unique perspectives to the jury.

As Chief Justice Burger suggested in his Batson dissent, ${ }^{78}$ the verdict of social science appears to favor the critics. In a thorough study of the social science data on the impact of race on jury verdicts, Nancy King recently demonstrated that juror race "can and does affect jury decisions." from unequivocal, the studies catalogued in King's article suggest differences in the ways that black and white jurors assess guilt when the defendant or victim is black, ${ }^{80}$ in the ways that black and white jurors assess the credibility of police testimony, ${ }^{81}$ in the ways that black and white jurors react to black defense counsel, ${ }^{82}$ and in the ways that black and white jurors determine sentences (in jurisdictions where they are permitted to do so). ${ }^{83}$ The social science data also suggest at least some differences in the ways in which male and female jurors are likely to vote in certain kinds of cases.

dissenting); Alschuler, supra note 11, at $201-03$.

This criticism, however, might focus on the wrong issue. The relevant question might not be uhether rationally exereised peremptory challenges are compelling or important state interests. but whether such challenges serve compelling or important state interests. See J.E.B., 114 S. Ct at 1438 (Scalıa. J. dissenting); Batson, 476 U.S. at 125 (Burger, C.J., dissenung). In any event. this Arucle is not concerned with the question of whether Batson itself represents a sound application of equal protection analysis. II is concerned with the separate question of whether Batson presents a sound account of the fair inal harm caused by the discriminatory peremptory challenge. See infra note 325.

The Court's newest member, Justice Breyer, has had no real opponunity to make his views known on the question of whether group affiliation is a rational predictor of juror perspectuve

77. See supra notes $30-46$ and accompanying text.

78. See 476 U.S. at 121 (Burger, C.J., dissenung) (quoung Babcock, supro note 66. at 553-54)

79. Nancy J. King, Posiconviction Review of Jury Discrimuahon. Aleasuring the Effects of Juror Race on Jury Decisions, 92 MICH. L. REV. 63, 99 (1993); see also Cammack, supra note 29. at $478-79$ (summarizing data from mock jury studies); Roberta K. Fowers. Does /I Cost Too bluch' A 'Difference' Look at J.E.B. v. Alabama, 64 FORDHAM L. REV. 491. 516-20 (199S) (summanzing soctal seience and literary materials); Sheri Lynn Johnson. Black Innocence and the Whue Jun. 83 MICH. L REv 1611. 1625-43 (1985) (same). But see Nancy S. Marder. Beyond Gender Perempton Challenges and the Roles of the Jury, 73 TEX. L. REV. 1041, 1080 (1995) (disputing predictive value of group affiliation for voung preferences).

80. See King, supra note 79 , at $81-85$.

81. See id. at 88: see also Tracey Maclin, "Block and Bluc Encounters"-Some Preluminan Thoughts About Fourth Amendment Seizures: Should Race Matter'. 26 VAL. U. L. REV 243, 250-62 (1991) (analyzing relations between African-American men and police): Richard A. Wasserstrom. Rucism. Sextsm. and Preferential Treatment: An Approach to the Toptcs, 24 UCLA L. REV. 581.598 (1977) (describing unconscious racial prejudice based on perceptions of police behasior)

82. See King, supra note 79 , at $88-89$.

83. See id. at 95-98. Jury sentencing, even in the noncaptal context. is stull permulted in some circumstances in Arkansas, Kentucky, and Texas. See ARK CODE ANN \$ 5-4-103 (Michte 1993) (permitting jury sentencing of defendants convicted of felony after jury tnal). KY REV STAT ANN \$ 532.055(2) (Michie Supp. 1994) (same); 3A TEX. CRIM. PROC. CODE ANA. \$37 07(2)(b) (Wesi Supp 1996) (permitting jury sentencing only on electuon of defendant)

84. See REID HASTIE ET AL, INSIDE THE JURY 140-12 (1983): Marder, supra note 79, al 1070-73 (citing studies suggesting difference between men's and women's assessments of reliability of eyewiness identifications). 
The verdict of public opinion also seems to favor the Batson critics on the question of whether group affiliation is a rational predictor of juror perspective. ${ }^{85}$ One need only have witnessed the nationwide reaction to the verdicts in the two prosecutions of the Los Angeles police officers who beat Rodney King in order to know that the public believes that the racial makeup of juries matters. Similarly, when two California juries failed to convict brothers Erik and Lyle Menendez for killing their parents, much public discussion and outcry centered on the gender of the jurors and on the malefemale split in the jurors' receptivity to the defendants' allegations of sexual and emotional abuse. ${ }^{86}$ In addition, the media commonly report on the racial and gender composition of juries. ${ }^{87}$ For example, in the murder prosecution of O.J. Simpson, media coverage during jury selection emphasized the race and gender of the prospective jurors. ${ }^{88}$ Each time a juror was dismissed during the trial, the media immediately reported the effect that the dismissal had on the racial and gender composition of the jury. ${ }^{89}$ When Simpson was acquitted, the media again focused heavily on the race and gender of the jurors. ${ }^{90}$

Public opinion conforms to the observations of social science: race and gender are rational, even if grossly imperfect, proxies for perspective. ${ }^{9 t}$ The

85. Some might argue that the public's opinion on this issue is the most important of all, since it is the public that must ultimately accept or reject criminal verdicts as reliable pronouncements on basic moral questions. See Akhil Reed Amar, Sixth Amendment First Principles, 84 GEO. L.J. 641, 680-81 (1996) (arguing that "the public trial was designed ... to satisfy the public that truth had prevailed at trial" and to be "confidence-enhancing"). On the subject of the public acceptance of jury verdicts and the jury's public role, see Gary Goodpaster, On the Theory of American Adversary Criminal Trial, 78 J. CrIM. L. \& CRIMINOLOGY 118, 145-52 (1987); Marder, supra note 79, at 1052-63, 1077, 1095; Charles Nesson, The Evidence or the Event? On Judicial Proof and the Acceptability of Verdicts, 98 HARV. L. REV. 1357. 1366-69 (1985).

86. See, e.g., Female Jurors Assert Sexism Hurt Menendez Deliberations, N.Y. TIMES, Jan. 31, 1994, at A13; Amy Wallace \& Bob Pool, Jurors' Rift Emerged Early and Ran Deep, L.A. TimEs, Jan. 29, 1994. at Al.

When the Menendez brothers were convicted by a single jury at their retrial, press reports noted that unlike the earlier juries, which had broken down into "cliques" largely along gender lines, the seven-man, five-woman jury on retrial "seem[ed] to get along." Ann W. O'Neill, Menendez Retrial Plays Differently, L.A. TIMES, Mar. 3, 1996, at A1; see also Ann W. O'Neill, Menendezes Are Found Guilty of Killing Parents, L.A. TIMES, Mar. 21, 1996, at Al.

87. See Georgia v. McCollum, 505 U.S. 42, 61 n.1 (1992) (Thomas, J., concurring) (noting frequent use of phrase "all white jury" in major newspapers).

88. See, e.g., Tony Freemantle, Jury Makeup Favors Simpson, Experts Say: Eight of Twelve Picked to Hear Case Are Black, Hous. Chron., Nov. 5, 1994, at 5; Janet Gilmore \& Mark Katches, More. Men. Latinos in Simpson Alternate Jury Pool, L.A. DAlLY NEwS, Dec. 7, 1994, at N6; Mark Katches \& Janet Gilmore, Jury Pool's Racial Composition Favors Simpson, Analysts Say, L.A. DAllY NEwS, Nov. 1. 1994, at NI; Mostly Black and Female Jurors Make Up Alternate O.J. Panel, FT. LAUderdale SUN-SENTINEL, Dec. 9, 1994, at 3A; Roger Simon, Poor Blacks May Hold Simpson's Fate, BALTIMORE SUN, Oct. 12, 1994. at $1 \mathrm{~A}$.

89. See, e.g., Jim Newton \& Andrea Ford, Criminalist Concedes Errors; Panelist Ousted, L.A. Times, Apr. 6, 1995, at Al (dismissing juror "did not change the gender or ethnic makeup of the panel . . as one black woman was replaced with another").

90. See, e.g., A Profile of the Jury, N.Y. TIMEs, Oct. 4, 1995, at All.

91. See Alschuler, supra note 11, at 169 n.65 ("[J]ust as blacks and whites may favor Jesse Jackson for President in different ratios, blacks and whites may-if regarded collectively and statistically-approach the issues that arise in some criminal cases differently."); Katherine Goldwasser, Limiting a Criminal Defendant's Use of Peremptory Challenges: On Symmetry and the Jury in a Criminal Trial, 102 HARV. 
Court's suggestion to the contrary in Batson and its progeny is untrue to decades of judicial efforts to open the jury to excluded groups, to the findings of social science, and to the beliefs of the public, who must either accept or reject jury verdicts as reliable resolutions of important moral questions.

\section{Harmless ERror, Reliability, and the Rise of the SCIENTISTIC VERDICT}

While clinging to the view that group affiliation is a rational predictor of juror perspective, the Court's conservative core of Batson critics has also been busy overseeing a revolution in the law of criminal appellate remedies. Where constitutional error in the investigation or prosecution of a criminal case once triggered automatic appellate reversal on direct appeal, regardless of the impact of that error on the jury's verdict, very nearly the opposite is now true. Where the Court once exercised the power of appellate review to enforce respect for a great number of the values served by the criminal process, it now exercises that power to protect only one value: reliable truthfinding. The tale of this turnabout has been told before, ${ }^{92}$ but it bears summarizing here, for it has serious ramifications for the views of both the champions and the critics of the Batson norm.

Through the end of the nineteenth century, the remedy for error in the American appellate courts was the remedy known at English common law: automatic reversal of the defendant's conviction. ${ }^{93}$ Reversal was the remedy regardless of how trivial or technical the error was. Needless to say, this made for some downright silly results. Justice Traynor, in his book on harmless error, tells of a California case, People v. St. Clair, ${ }^{24}$ in which the appellate court reversed a conviction because the indictment, alleging the defendant's entry into a building with intent to commit larceny, omitted the letter " $n$ " from the word "larceny." 95

The silliness of certain outcomes under this common-law rule should not, however, blind us to what the rule revealed about the nature of the criminal process. In such a regime, where all sorts of errors resulted in automatic reversal, appellate courts used the remedy of reversal to enforce a very broad range of values in the criminal process. For example, reversal was appropriate for an error which offended an important constitutional value such as the

\footnotetext{
L. REV. 808, 834 n.165 (1989); Ogletree, supro note 11, at 1104 (".TThe roles and life expenences of men and women . . . are still unfortunately different enough that it is rational to believe that randomly selected women will view a case differently from randomly selected men ").

92. See Charles J. Ogletree, Jr., Arizona v. Fulminante: The Harm of Applsing Harmless Error to Coerced Confessions, 105 HARV. L. REV. 152, 156-61 (1991).

93. See id. at 156.

94. $56 \mathrm{Cal} .406$ (1880). 406).

95. See Roger J. Traynor, The RIddle of Harmless ErRor 3-4 (1970) (ciung St Clair. S6 Cal
} 
individual's right not to incriminate himself, ${ }^{96}$ even if that error did not have the slightest impact on any other value in the criminal process, such as the discovery of truth. ${ }^{97}$ In other words, the common-law rule of automatic reversal reflected a belief that the criminal process served a great number of important values, and that the sanction of reversal protected those values embedded in the criminal process for their own sake.

As might be expected, however, cases like St. Clair prompted doubt about whether appellate courts should enshrine correct spelling as an important value in the criminal process. Public pressure mounted for a rule that would permit a conviction to stand when the error in the trial court was trivial. ${ }^{98}$ Congress responded to this pressure in 1919 , when it enacted a harmless error rule for cases in the federal courts. ${ }^{99}$ All fifty states did the same, eventually enacting their own harmless error rules for proceedings in their courts. ${ }^{100}$ The Supreme Court, however, continued to abide by the old rule of automatic reversal for constitutional error when it reviewed state criminal cases on direct appeal. $^{101}$

The Court's landmark 1967 opinion in Chapman v. California ${ }^{102}$ marked the end of the old rule of automatic reversal. In Chapman, the Court reviewed the robbery, kidnapping, and murder convictions of two defendants who had declined to testify in their own defense at their state court trial. ${ }^{103}$ The prosecutor had commented extensively on their silence in his summation to the jury. Though this sort of prosecutorial comment enjoyed the full blessing of California's constitution, ${ }^{104}$ the Supreme Court's decision in Griffin v. California-issued while the Chapman case was still on appeal-condemned it as a violation of the privilege against self-incrimination in the Fifth

96. See U.S. CONST. amend. V ("No person ... shall be compelled in any criminal case to be a witness against himself.").

97. See, e.g., Haynes v. Washington, 373 U.S. 503, 518-19 (1963) (citing Rogers v. Richmond, 365 U.S. 534, $541(1961))$.

98. See Ogletree, supra note 92 , at 156.

99. See Act of February 26, 1919, ch. 48,40 Stat. 1181. The idea contained in that Act survives both in the federal statute books and in the federal rules. See 28 U.S.C. \$2111 (1994) ("On the hearing of any appeal or writ of certiorari in any case, the court shall give judgment after an examination of the record without regard to errors or defects which do not affect the substantial rights of the parties."); FED. R. CRIM. P. 52(a) ("Any error, defect, irregularity or variance which does not affect substantial rights shall be disregarded.").

100. See Chapman v. California, 386 U.S. 18, 22 (1967) ("All 50 Stales have harmless-error statutes or rules.").

101. See id. at $42-45$ (Stewart, J., concurring in judgment).

102. 386 U.S. 18 (1967).

103. See id. at $19,24-26$.

104. The Chapman Court noted:

At the time of the trial, Art. I, $\$ 13$ of the State's Constitution provided that in any criminal case, whether the defendant testifies or not, his failure to explain or to deny by his testimony any evidence or facts in the case against him may be commented upon by the court and by counsel, and may be considered by the court or the jury.'

Id. at 19 (quoting CAL. CONST. art. I, § I3). 
Amendment to the United States Constitution. ${ }^{105}$ Thus, when the Chapman case arrived in the Supreme Court, it presented a plain and unmistakable constitutional error.

Under the then-prevailing rule, that was all the Supreme Cour needed to know: the remedy for constitutional error was automatic reversal. ${ }^{100}$ The Court, however, used the Chapman case to craft a harmless error rule for direct review of state court convictions. ${ }^{107}$ Recognizing the usefulness of a rule that would "block setting aside convictions for small errors or defects that have little, if any, likelihood of having changed the result of the trial," 103 the Court determined that it was necessary to inquire whether there was a "reasonable possibility" that the error ".might have contributed to the conviction." 109 Chapman narrowed the range of values in the criminal process that deserved protection through the sanction of automatic reversal on appeal. The "result of the trial" 10 began to eclipse the details of the trial process itself as the lodestar value of the criminal justice system.

Since Chapman, the Court has added one constitutional error after another to the list of errors amenable to harmless error analysis." In doing so, the Court has made unmistakably clear what it first intimated in Chapman-namely, that "the central purpose of a criminal trial is to decide the factual question of the defendant's guilt or innocence." 112 Criminal trials must be "reliabl[e] . . . vehicle[s] for determination of guilt or innocence."

105. See Griffin v. Califomia, 380 U.S. 609. 613-15 (1965) The Fifth Amendment was made applicable to the states through the Foureenth Amendment in Mallov v. Hogan. 378 U S 1 (196-t)

106. See Chapman, 386 U.S. at $42-45$ (Stewar. J., concurnng in judgment)

107. There was something contnved about using Chapmon for this purpose, since the Coun uent on to hold that the Griffin error in the case was not harmless. See id at 24-26. One might have expected the Court to wait to craft a harmless error rule in a case where the rule actually made a difference Sull, the gratuitous Chapman rule has never been treated as dictum.

108. Id. at 22.

109. Id. at 23 (quoting Fahy v. Connecucut. 375 U S 85. 86-87 (1963)) The Coun has cteated considerable confusion in the lower cours by contunually reformulatung the Chapman harnless error standard in subsequent cases. See Manha A. Field. Assessing the Harmlessness of Federal Constitutuonal Error-A Process in Need of a Rationale, 125 U. PA. L. REV 15 (1976): Gregon Mitchell. Against "Overwhelming" Appellate Activism: Constraining Harmless Error Restew. 82 CAL. L REV 1335. 1341-47 (1994); Tom Stacy \& Kim Dayton, Rerhinking Harmless Consututtonal Error. 88 Coll 4 L REV $79,126-42$ (1988).

110. Chapman, 386 U.S. at 22.

111. Chief Justice Rehnquist included an exhaustive hist of these errors (as of 1991) in his opinion in Arizona v. Fulminante, 499 U.S. 279. 306-07 (1991) (Rehnquist. C J . for Coun in pan and dissenting in part). Since Fulminante, the list has continued to lengthen. See Brecht v. Abrahamson. $113 \mathrm{~S} \mathrm{Cl} 1710$. 1713-14 (1993) (holding prosecution's use of defendant's post-M/randa silence for impeachment purposes amenable to harmless error review); Yates v. Evalt, 500 U.S. 391.402 (1991) (applung harmless error analysis to taint of unconstitutional burden-shifting jury instruction)

112. Delaware v. Van Arsdall, 475 U.S. 673.681 (1986) (ciung Untled States v Niobles, $\$ 22$ L S 225. 230 (1975)).

113. Rose v. Clark, 478 U.S. 570, 577-78 (1986) (cunng Pow ell v Alabama. 287 U S 45 (1932)) For a detailed analysis of the Cour's shift to a reliability-based model of cnminal procedure, see Tom Stacy. The Search for the Truth in Constututional Crimmal Procedure. 91 CoLuM. L REV 1369 (1991) See also King, supra note 79, at 116 (noting that "the goal of ensurng the factual accuracy and reltabilaty of criminal convictions and sentences... has become the dnung force behind much of the cnminal procedure jurisprudence of the present Court"): Ogletree, supra note 92. at 162 ("/A]ccuracy in the determination of 
Harmless error analysis, according to the Court, is "essential to preserve" this "central purpose" of the criminal trial: ${ }^{114}$ Only when errors seriously undermine the truthfinding function do they merit reversal on appeal.

Chapman itself did not singlehandedly eliminate all values other than reliability from protection through appellate reversal. Indeed, the Chapman Court made clear that certain errors undermined rights "so basic to a fair trial" "Is that a court need not even examine the impact of those errors on the reliability of the verdict before reversing a conviction. Among these rights the Court placed the right to counsel, the right to the suppression of coerced confessions, and the right to an unbiased judge. ${ }^{116}$ What the Chapman Court did not say, however, was precisely why those types of errors should not be subject to harmless error analysis. Was it because those errors vitiated values that were important enough, in and of themselves, to deserve protection through the sanction of reversal? Or was it because those errors presumptively did such great damage to the value of reliability that reviewing courts could safely be spared the formality of harmless error analysis?

The Court suggested an answer to this important question in the early 1980s. In the landmark case of Strickland v. Washington, ${ }^{117}$ the Court fixed a standard of minimal effectiveness for the "counsel" to which a criminal defendant is entitled under the Sixth Amendment. ${ }^{118}$ The Court noted that in defining "effective assistance of counsel," it had to take the "purpose [of that constitutional requirement]- to ensure a fair trial-as the guide." 119 The Court continued: "This requires showing that counsel's errors were so serious as to deprive the defendant of a fair trial, a trial whose result is reliable." ${ }^{20}$ Hence reliability does not supplement or result from fairness; it equates with fairness. Strickland supplied a significant hint that values of fair process were

guilt is the value that matters most to the Court in the criminal context."); Louis Michael Seidman, Fuctual Guilt and the Burger Court: An Examination of Continuity and Change in Criminal Procedure, 80 CoLUM. L. REv. 436, 437 (1980) (noting that Burger Court's rhetoric "focused on the need to reorient the criminal justice system toward a model designed primarily to achieve accurate factual determinations of guilt or innocence in individual cases").

114. Fulminante, 499 U.S. at 308 (quoting Van Arsdall, 475 U.S. at 681 ).

115. Chapman v. Califomia, 386 U.S. 18, 23-24 (1967).

116. See id. at 23 n. 8 (citing Gideon v. Wainwright, 372 U.S. 335 (1963) (right to counsel); Payne v. Arkansas, 356 U.S. 560 (1958) (coerced confessions); Tumey v. Ohio, 273 U.S. 510 (1927) (unbiased judge)). Indeed, on this point, the Chapman Coun was unanimous: All nine Justices agreed that these threc types of error could never be harmless. See Chapman, 386 U.S. at $42-44$ (Stewart, J., concurring in judgment); id. at 52 n.7 (Harlan, J., dissenting).

117. 466 U.S. 668 (1984).

118. The Court held that a defendant seeking to prove that his attorney was constitutionally ineffective must prove that "counsel's representation fell below an objective standard of reasonableness," id. at 688 , and must also show "a reasonable probability that, but for counsel's unprofessional errors, the result of the proceeding would have been different," id. at 694.

119. Id. at 686 .

120. Id. at 687 (emphasis added). 
losing their intrinsic worth, and were instead becoming means to the ultimate end of verdict reliability. ${ }^{121}$

The Court turned this hint into unambiguous law in Arizona $v$. Fulminante. ${ }^{122}$ There the Court took back something that it seemed to have given in Chapman: It held that the admission into evidence of a coerced confession is subject to harmless error analysis. ${ }^{123}$ The Court changed its mind about coerced confessions because it decided that a record on appeal could adequately show whether an improperly admitted confession undermined the reliability of the verdict as a statement of truth. ${ }^{124}$ The Court acknowledged that obtaining confessions through coercion is "reprehensible" police conduct that undermines deep constitutional values. ${ }^{125}$ The Cour simply believed that these were not the values that appellate reversal exists to protect. Convictions should be reversed only when errors undermine the value of verdict reliability.

The Court did continue to insist that a certain (very small) group of socalled "structural" constitutional errors should still merit automatic reversal. These "structural" errors- "structural defects in the constitution of the trial mechanism, which defy analysis by "harmless-error' standards"126-are distinguished from the much larger number of so-called "trial errors," which permit harmless error analysis. "Structural" errors include the total deprivation of the right to counsel, the lack of an impartial judge, the denial of the right to self-representation at trial, the denial of the right to a public trial, and the exclusion of members of a defendant's race from a grand jury. ${ }^{127}$ By

121. For a persuasive account of the Court's growing "preoccupation with reliability" in its cnminal procedure decisions of the 1980s, see Stacy \& Dayton, supra note 109. at 82-88.

122. 499 U.S. 279 (1991).

123. Fulminante produced a somewhat confusing alıgnment of Jusuces in its several opınons The net result was that Fulminante's confession was held to have been cocreed. but the admission of that confession was held not to be harmless error. A majority of the Court (Jusuces White, Marshall. Blackmun, Stevens. and Scalia) held that Fulminante's confession was coereed. See id. at 287. A different majonty (Chuef Justice Rehnquist and Justices O'Connor, Scalia. Kennedy, and Souter) held that notwithstanding contrary language in Chapman, the admission of coerced confessions should be subjected to harmless error analysis. See id. at 306-12; id. at 313-14 (Kennedy, J., concurring in judgment). Yet a third majonty (Justuces White, Marshall, Blackmun, Stevens, and Kennedy) held that on the facts of this case, the admission of Fulminante's confession was not hamless. See id, at 295-302: id. at 313-14 (Kennedy. J.. coneumng in judgment).

In its method of subjecting coerced confessions to harmless error analysis. Fulminante presents an odd parallel to Chapman. In Chapman, where the Cour first adopted a hamless crror rule, the Courn need not have formulated a harmless error rule at all, since the Justices were of the view that the prosecutor's summation comments on the defendants' failure to testify were unquestionably hamful. See supra texi accompanying note 106. In Fulminante, four of the five Justices who agreed that harmless error analysis should apply to the admission of coerced confessions were also of the view thal there was no error in the case at all-that is, that the confession was not coereed. Consequently. much of the groundbreaking law of harmless error has been made by Justices who, under the terms of thesr own analysis. need not have reached the question of harmless error at all.

124. See Fulminante, 499 U.S. at 310 (Rehnquist, C.J., for Court in part and dissenting in part).

125. Id. at 311 (Rehnquist. C.J., for Court in part and dissenting in part).

126. Id. at 309 (Rehnquist, C.J., for Court in part and dissentung in part).

127. See id. (Rehnquist, C.J., for Coun in part and dissentıng in pan) (citıng Vasquez v. Hillery. 474 U.S. 254, 264 (1986) (grand jury discrimination); Waller v. Georgı, 467 U.S. 39.49 n.9 (1984) (public 
preserving a small category of automatically reversible constitutional errors, the Fulminante opinion might be read to suggest that certain important values in the criminal process other than reliability still qualify for appellate protection through a rule of per se reversal.

However, Fulminante offers no protection to values other than accurate fact-finding. Chief Justice Rehnquist made clear that the handful of "structural" constitutional errors continue to trigger automatic reversal not for their own sake, but because everyone implicitly understands that such errors always make verdicts inaccurate. ${ }^{128}$ According to Fulminante, a defendant is entitled to automatic reversal of his conviction upon the complete denial of, for example, his right to counsel not because the denial of that right offends the values of dignity or fair play, but because without this "basic protection[], a criminal trial cannot reliably serve its function as a vehicle for determination of guilt or innocence." 129 "Structural error," according to the Court, is a specific kind of flaw in the constitution of the trial mechanism-a flaw the precise effect of which we cannot measure from a cold appellate record, but which "obviously affect[s]" the "entire conduct of the trial from beginning to end." "While the practice of automatic reversal survives Fulminante, appellate protection of values other than reliable fact-finding simply does not. ${ }^{131}$

trial); McKaskle v. Wiggins, 465 U.S. 168, 177 n.8 (1984) (self-representation at trial); Gideon v. Wainwright, 372 U.S. 335 (1963) (right to counsel); Tumey v. Ohio, 273 U.S. 510,523 (1927) (biascd judge)). The Hillery case is something of an aberration on this list; it is discussed more fully infra Section IV.D.

In Sullivan v. Louisiana, 508 U.S. 275 (1993), the Court added another constitutional error to the list of errors subject to automatic reversal-a constitutionally deficient instruction on the standard of proof beyond a reasonable doubt. Interestingly, however, the Court did not rely primarily on Fulminante's distinction between "structural" and "trial" errors. Rather, the Sullivan Court held that the trial court's failure to give an accurate instruction on proof beyond a reasonable doubt deprived the defendant of a "jury" within the meaning of the Sixth Amendment, and thereby left the reviewing court without a truc "verdict" on which to perform harmless error analysis. See id. at 277-78. The Court relied on Fulminante's distinction between "structural" and "trial" error only in passing, as an alternative basis for the decision. See id. at 278-79. Perhaps the Sullivan Court's reluctance to embrace Fulminante's dichotomy of crrors reflects some of the same discomfort that that schema has created in the law reviews. See, e.g., Linda E. Carter, Harmless Error in the Penalty Phase of a Capital Case: A Doctrine Misunderstood and Misapplied, 28 GA. L. REV. 125, 140-43 (1993); Henry Monaghan, Harmless Error and the Valid Rule Requirement, 1989 SUP. CT. REV. 195, 204; Ogletree, supra note 92, at 162-64; Stephen L. Earnest, Recent Decision, 61 Miss. L.J. 445, 457-58 (1991).

128. See, e.g., Scarpa v. Dubois, 38 F.3d 1, 14 (1st Cir. 1994) ("In effect, then, the harmfulness of structural errors can be conclusively presumed."), cert. denied, 115 S. Ct. 940 (1995).

129. Fulminante, 499 U.S. at 310 (Rehnquist, C.J., for Court in part and dissenting in part) (emphasis added) (quoting Rose v. Clark, 478 U.S. 570, 577-78 (1986)).

130. Id. at 309 (Rehnquist, C.J., for Court in part and dissenting in part); see also Brecht v. Abrahamson, 507 U.S. 619, 629-30 (1993) (holding that structural errors "require[] automatic reversal of the conviction because they infect the entire trial process"); Delaware v. Van Arsdall, 475 U.S. 673, 68I (1986) (noting that some constitutional errors are automatically reversible because their effects are "fundamental and pervasive" (emphasis added)).

131. Vasquez v. Hillery, 474 U.S. 254 (1986), sits uncomfortably in Fulminante's list of structural errors requiring automatic reversal. After Fulminante, appellate reversal requires some type of harm to the reliability of the petit jury's verdict-either demonstrable harm in the case of trial error, or presumable harm in the case of structural error. The Hillery case, however, concerned the exclusion of blacks from the grand jury. See id. at 255-56. Modern grand juries are notoriously dependent on, and controlled by, the 
But what exactly is the nature of the "reliability" that the Fulminante Court enthrones as the reigning value in the criminal appellate process? Is it a process-based reliability, under which a "reliable" verdict is any verdict that emerges from a trial that rigorously adheres to fair procedures? Or is it instead an empirical reliability, under which a "reliable" verdict is a verdict that accurately describes the historical fact of whether the defendant actually committed the crime?

It is the latter. Fulminante's language at least hints, if it does not affirmatively state, that the Court had in mind an empirical model of the criminal verdict. The Court made clear that when a jury determines a defendant's guilt or innocence-that is, when it performs "'the central purpose of a criminal trial" - the jury is deciding a "'factual question.".132 If a reliable verdict were simply whatever pronouncement on a defendant's guilt or innocence a fairly conducted trial happened to produce, it would be odd to refer to that finding as a "fact."

More importantly, the change in the law that Fulminante worked shows clearly that the Court was rejecting a process-based understanding of reliability for an empiricist understanding. If a reliable conviction were any conviction obtained through the application of fair trial procedures, then we would expect the Court to deem verdicts unreliable, and therefore automatically reversible, whenever fair trial procedures were flaunted. Trial procedures, in other words, would have value in their own right; they would be the essential determinant of a reliable verdict. Yet Fulminante is striking precisely because the Court walked away from this approach. Trial procedures have no intrinsic value for the Fulminante Court; they merit concern only when their distortion causes a parallel distortion of the accuracy of the jury's reconstruction of real-world events. As Tom Stacy and Kim Dayton have argued, this type of reasoning positively "denigrates" the fair trial rights of criminal defendants. ${ }^{13}$

prosecutor. See infra text accompanying note 206. Whatever might be sald of the harn that racial excluston causes to the verdict pronounced by an independent and autonomous pett jury. the same cannot be said for the impact of racial exclusion on the indictment produced by a subservient grand jurn See infra Section IV.D.

The right to self-representation at trial also seems out of place in Fulminante's list That constitutional right, recognized in Faretra v. Californa, 422 U.S. 806 (1975), hardly seems to enhance the relıabilsty of criminal vendicts. Indeed, it might be seen to do just the opposste If the nght to representation by trained counsel is essential to the rigorous process of adversanal tesung that ke take to establish truth. as the Court has said it is, see Gideon v. Wainwright. 372 U.S. 335. 342-45 (1963), then it is difficult to understand how the right of a layperson to refuse trained counsel and go 11 alone does not frustrate this seareh Nonetheless, the Court has continued to treat the denial of the nght to self-representation as a structural error requiring reversal. See McKaskle v. Wiggins, 465 U.S. 168. $177 \mathrm{n.8}$ (198f) ("Since the nght of selfrepresentation is a right that when exercised usually increases the likelihood of a tnal oulcome unfavorable to the defendant, its denial is not amenable to 'harmless error' analysis."). The rule of automatic reversal for denial of the right to self-representation is at odds with the single-minded focus on reliable verdicts that animates Fulminante and most of the Court's other crimanal procedure cases of the last tifteen years

132. Fulminante, 499 U.S. at 308 (Rehnquist. C.J., for Courn in pan and dissenung in part) (quoung Delaware v. Van Arsdall, 475 U.S. 673. 681 (1986)) (emphasis added)

133. Stacy \& Dayton, supra note 109, at 80-81. Stacy and Dayton were not here efefernng to Fulminante, as their excellent article preceded that decision They were. houeler. eferming to a number 
Fulminante's reasoning establishes what the language of the opinion intimates: A "reliable" verdict is a verdict that accurately describes the historical truth about the defendant's involvement in, and responsibility for, the crime.

Fulminante, moreover, was not decided in a vacuum. It was decided at a time when the same majority that favored the extension of harmless error analysis to coerced confessions was also busily reforming the law of habeas corpus. There too, in the habeas setting, these Justices have clearly articulated an empiricist understanding of the nature of the criminal verdict. ${ }^{134}$ As Justice O'Connor stated in her plurality opinion in Teague $v$. Lane, ${ }^{135}$ the Court's habeas cases "have moved in the direction of reaffirming the relevance of the likely accuracy of convictions in determining the available scope of habeas review." 136 For example, as the Court has raised new bars to federal courts' consideration of procedurally defaulted claims of constitutional error ${ }^{137}$ and to claims of constitutional error presented in successive federal habeas petitions, ${ }^{138}$ the Court has recognized that a habeas petitioner may avoid these bars through a colorable claim of "actual innocence" of the crime or crimes charged. ${ }^{139}$ By creating this exception, the Court restricts federal court review to those state court verdicts that are empirically, demonstrably false factual findings. To take this step, the Court must believe that criminal. verdicts are, in essence, empirical findings in the first place.

In Teague itself, where a plurality of the Court stated that it would no longer announce new rules of constitutional criminal procedure in habeas cases, ${ }^{140}$ the Court allowed an exception for only "those new procedures without which the likelihood of an accurate conviction is seriously diminished."141 The plurality made plain that the "accurate conviction" it was seeking to ensure was the accurate conviction of the factually guilty: The purpose of allowing federal courts to announce new rules of constitutional

of cases from the late 1970s and early- to mid-1980s that suggested the approach to the criminal verdict that Fulminante adopted. See id. at 80 n.9.

134. See Jordan Steiker, Innocence and Federal Habeas, 41 UCLA L. Rev. 303, 304 (1993) ("As the Court has narrowed the reach of the writ, it has repeatedly emphasized that the availability of habeas relief should depend in large measure on whether the petitioner is factually innocent.").

135. 489 U.S. 288 (1989).

136. Id. at 313 (O'Connor, J., plurality opinion).

137. See, e.g., Coleman v. Thompson, 501 U.S. 722, 748 (1991) (holding that where habeas petitioner missed filing deadline for direct appeal from state court conviction, federal district court may address claims of constitutional error only if petitioner can show cause for default and actual prejudice flowing from claimed ertor).

138. See, e.g., McCleskey v. Zant, 499 U.S. 467, 493 (1991) (adopting cause-and-prejudice test for claims of constitutional error not presented in first federal habeas petition).

139. See, e.g., Schlup v. Delo, 115 S. Ct. 851,862 (1995) (allowing successive petition upon appropriate showing of actual innocence).

140. See Teague, 489 U.S. at 310,316 . Although Teague produced only a plurality opinion, its rulc has been applied in subsequent majority opinions. See, e.g., Butler v. McKellar, 494 U.S. 407, 409 (1990) (applying Teague to question of lawfulness of custodial interrogation on particular set of facts); Penry v. Lynaugh, 492 U.S. 302, 314 (1989) (stating that Teague applies to whether Constitution permits exccution of mentally retarded prisoner).

141. Teague, 489 U.S. at 313. 
criminal procedure in habeas cases was to "assure that no man has been incarcerated under a procedure which creates an impermissibly large risk that the innocent will be convicted." 142 Thus whatever went unsaid in Fulminante about the empirical nature of criminal verdicts has been stated quite clearly in the Court's recent habeas corpus cases. ${ }^{143}$ That statement is nothing short of an "exaltation"144 of factual accuracy. ${ }^{145}$

Fulminante represents the crowning victory in a battle to restrict appellate remedies for error in the criminal process. ${ }^{146}$ Yet it also represents something deeper: a fundamental commitment to a specific model of the criminal verdict. By hinging appellate reversal on an impairment of the "reliability" of the verdict, the Court is saying quite clearly that a criminal verdict is not a subjective judgment or a socially constructed consensus. A criminal verdict is

142. Id. at 312 (quoting Desist v. United States, 394 U.S 244, 262 (1969) (Harlan. J , dissenting)). see also id. at 320-22 (Stevens, J., concurring) (faulung Teague plurality for limutung federal habeas court's power to announce new rules to "factual innocence" standard)

143. Fulminante is, of course, a case about direct appellate review. rather than collateral review, and the Court has admittedly made clear that "collateral review is different from direct revieu " Brecht v Abrahamson, 113 S. Ct. 1710,1719 (1993). Yet the differences beiueen direel and collateral review do not suggest that the Coun has one image of what a criminal verdiet is in direct revien ases and a completely different image of the criminal verdict in collateral revieu cases. On collateral review, prnnciples of comity and federalism counsel greater hesitation before a federal reviewing coun will disturb a state criminal conviction. See id. at 1720-21. The Court held in Brecht, for example. that courns should use a less rigorous harmless error standard in habeas cases than in direct review eases See $t d$ at 1721-22 (directing habeas courts to determine whether error "had substantial and injunous effect or influence in determining the verdict" rather than whether error was "harnless beyond a reasonable doubt") This does not mean, however, that a criminal verdict is any less a finding of histoncal fact in one selling than the other. It simply means that a habeas coun must treat that finding more deferentually in order to avoud creating excessive friction between state and federal courts.

144. Smith v. Murray. 477 U.S. 527. 545 (1986) (Stevens. J . dissenung)

145. I do not mean to suggest that concerns for the factual accuracy of criminal verdicts have dnven each and every one of the Burger and Rehnquist Courts' habeas opintons. Nolably, the Coun has declined several significant invitations to eliminate habeas review for clams not direcily impugning the factual accuracy of verdicts. See, e.g., Withrow v. Willsams, 507 U.S. 680 (1993) (allowing habcas review of claimed violation of defendant's rights under Miranda v. Anzona, 384 U.S $\$ 36$ (1966)). Rose v Mitchell. 443 U.S. 545 (1979) (allowing habeas review of clam of racial discrimination in selection of grand jury)

I do believe, however, that most of the Court's work in the habeas area for the last two decades has been animated by concerns for factual accuracy. See supra note 134 Indeed. I argue in this Article that the Court's heightened concem for factual accuracy. especially in recent years, has likely undermined the reasoning in Mitchell. See infra notes 200-04 and accompanyung text.

146. Of course, this is a victory that has been realized only in the appellate setung Trial courts stall enforce some rules that are designed primarily to deter police misconduct. irrespective of impact on the reliability of the jury's factfinding. Obvious examples of such rules an the exclustonary nule. which requires the suppression of evidence seized in volation of the defendant's Fourth Amendment nghts. see Mapp v. Ohio, 367 U.S. 643. 655 (1961), and the rule of Miranda v Arizona, $38+$ U S $\$ 36$ (1966), which forbids the prosecution from using an admission taken from a suspect in police custody who has not been informed of her constitutional rights to silence and counsel

On appeal, however, the prophylactic and deterrence-based rationales for these nules collapse Violations of these rules at trial are not automatically reicrsible; they are reversible only if they ham the reliability of the verdict. See Arizona v. Fulmunante, 499 U.S 279. 292 n.6 (1991) (White. J. for Court in part and dissenting in part) (citing cases establıshing that Miranda volations are reviewed for hamless error); Bumper v. North Carolina, 391 U.S. 543. 550 (1968) (holdıng volatıons of exclustonary rule subject to harmless error analysis); of. Nix v. Williams. 467 U S. 431.443 n.4 (1984) (adopung "inevitable discovery" exception to Fourth Amendment exclusionary rule in part on basis of exception's conceptual similarity to independent source doctrine). 
instead a factual finding that is capable of being "reliable"; it can be "true" in the same way that the results of a chemistry experiment can be "true." Just as laboratory error might contaminate an experiment and make its results unreliable, trial or structural error might contaminate a jury's deliberations and make its verdict unreliable. This, then, is a major consequence of the conservative Justices' victory in the harmless error battle-a scientistic definition of the criminal verdict. ${ }^{147}$

\section{THE CuRIOUS HARMLESSNESS OF BATSON ERROR: THE VIEWS OF BATSON'S PROPONENTS}

The Supreme Court has not yet directly addressed the question of whether a Batson error should trigger harmless error analysis or automatic reversal. ${ }^{148}$

147. Mark Cammack has perceptively tied this prevailing view of the criminal verdict to the empiricist epistemology of the Enlightenment. See Cammack, supra note 29, at 410-15, 422-62; see also Brown, supra note 27, at 140-47 (discussing "foundationalist" and "antifoundationalist" understandings of jury decisionmaking). This philosophy of knowledge works from the premise that the world has an objective, empirical reality independent of the mind of a person observing it. The observer's mind is a blank slate; it comes to know the world around it only through the observer's senses. What the observer knows is "true" only to the extent that the observer's mental representation accurately corresponds to the objective, empirical nature of the thing observed. See Cammack, supra note 29, at 410-15.

Cammack notes that "[i]n recent years, the premises of empiricism ... have been subjected to sustained attack across all of the disciplines they once held." $l d$. at 415 . The main attack has been "contextualist" - an attack on the notion that a bright line separates the subjective mind of the observer from the objective world that he observes. See id. at 415-21. This modern epistemology emphasizes the importance of context to the construction of knowledge, insisting that "representations of reality are shaped by the values and purposes of their human creators." $I d$. at 417 . Cammack suggests that the entire Court has clung to the empiricist model of the criminal verdict in Batson and its other jury selection cascs. See id. at 456. I do not agree; I see in the opinions of Batson's opponents a strong-and quitc powerful-commitment to contextualism. See infra note 213 and accompanying text.

148. The Court has addressed two related questions. First, in Vasquez v. Hillery, 474 U.S. 254, 255-56 (1986), the Court held that racial discrimination in the selection of grand jurors required reversal of the defendant's conviction, even though the defendant had been properly convicted by a lawfully constituted petit jury. Whether Hillery should be extended to the Batson setting, and indeed, whether Hillery was correctly decided, is discussed infra Section IV.D. Second, the Court has determined that Batson does not apply retroactively on collateral review of convictions that became final before Batson was decided. See Allen v. Hardy, 478 U.S. 255, 260 (1986) (per curiam). Part of the Court's rationale was that Batson error does no serious harm to criminal verdicts. See infra note 187.

One lower federal court has addressed the question of whether Batson error can be harmless on direct appeal. In United States v. Thompson, 827 F.2d 1254 (9th Cir. 1987), the court, citing Hillery, explicitly rejected the government's argument that Batson error can be harmless. See id. at 1261. Other federal courts and judges have suggested that Batson error cannot be Fulminante-style trial error but is instead structural error. See, e.g., Rosa v. Peters, 36 F.3d 625, 634 n.17 (7th Cir. 1994); Ramseur v. Beyer, 983 F.2d 1215 , 1225-26 n.6 (3d Cir. 1992); Blair v. Armontrout, 976 F.2d 1130, 1143 n.2 (8th Cir. 1992) (Heancy, J., concurring in part and dissenting in part).

The state courts have taken conflicting positions. Some have stated that Batson error cannot be harmless. See, e.g., K.S. v. Carr, 618 So. 2d 707, 711 (Ala. 1993); State v. Pharris, 846 P.2d 454, 459 (Utah Ct. App. 1993); cf. Ex parte Yelder, 575 So. 2d 137, 138-39 (Ala. 1991) (requiring court to presume prejudice on defendant's claim of ineffective assistance of counsel for failure to raise Batson objection). Others have held that Batson error can be harmless in certain circumstances. See, e.g., Macon v. Statc, 652 So. 2d 33I, 333 (Ala. Crim. App. 1994) (finding Batson error harmless where excused juror would have been excused in any event to tend to ill relative); State v. Vincent, 755 S.W.2d 400, 403-04 (Mo. Ct. App. 1988) (finding black defendant suffered no harm from prosecution's use of all six of its peremptories to exclude blacks, because jury that was seated still had five blacks); Seubert v. State, 749 S.W.2d 585, 588 
Arguably, it has resolved the question by inference. In cases such as Batson, Powers, Edmonson, and J.E.B., where the Court has found a violation of the Batson norm, it has reversed the conviction or judgment outright without pausing to assess the harmlessness of the violation. ${ }^{149}$ In none of these cases, though, did the Court explicitly consider the application of harmless error analysis; it seemed merely to assume that reversal was necessary. ${ }^{150}$ The question of the appropriate appellate remedy for Batson error seems to remain open. $^{151}$

However, even a quick glance at the Court's impassioned rhetoric in its jury discrimination cases reveals that the Cour-or at least the group of Justices who have devised and extended the Batson rule-considers such discrimination to be a very serious matter. Jury discrimination, the Court has said, "offends the dignity of persons and the integrity of the courts,"152 "is at war with our basic concepts of a democratic society and a representative government," 153 and "raises serious questions as to the fairness of [judicial] proceedings." 154 Were the Court to be presented with the claim that a Batson error was harmless, it would likely conclude that a Batson violation is structural error, to which harmless error analysis does not apply, ${ }^{1 s s}$ and would promptly reverse the conviction. ${ }^{156}$

(Tex. Ct. App. 1988) (finding Batson error might be harmless where blacks were not signiticantly underrepresented on jury compared to percentage in group from which venire was drawn). res id on other grounds, 787 S.W.2d 68 (Tex. Crim. App. 1990) (en banc).

Outside the context of the Batson problem, the Coun has selected appellate remedies for centan criors in jury selection. For example, the Court has held that the erroneous denal of a "for cause" challenge is not automatically reversible so long as the biased juror is removed by a peremptory challenge See Ross v. Oklahoma, 487 U.S. $81,86-88$ (1988). The circuits are split on whether the erroneous denial of a peremptory challenge on other than Batson grounds should be automaucally reversible Sec, e.g. Kurk v Raymark Indus., 61 F.3d 147, 158-62 (3d Cir. 1995) (yes); United States v. Annigoni. 57 F 3d 739. 745 (9th Cir. 1995) (no); see also infra note 294 (descnbing Anntgon).

149. See Batson v. Kentucky, 476 U.S. 79, 100 (1986): Powes , Oho. 499 L' S 400.416 (1991) (reversing conviction); Edmonson v. Leesville Concrete Co.. 500 U.S. 614. 631 (1991) (reversing judgment); J.E.B. v. Alabama ex rel. T.B., 114 S. Ct. 1419. 1430 (1994) (reversing judgment). see also Powers, 499 U.S. at 414 (noting that Coun has "recognized that discrimination in the jury selection process may lead to the reversal of a conviction").

150. Sometimes the parties invited the Court to make this assumption. in Poivers. the State conceded that the conviction should be reversed if the Cour accepled the white defendant's argument that he had standing to object to the dismissal of black jurors. See Powers. 499 U S at $\$ 16$.

151. But see Dawson v. Delaware, 503 U.S. 159. 169 (1992) (Blackmun. J. concumng) (placing Batson error on list of errors to which Coun has refused to apply harmless error analysis)

152. Powers, 499 U.S. at 402.

153. Smith v. Texas, 311 U.S. 128, 130 (1940) (holdıng that factally race-neutral system for grand jury selection was applied in illegally discriminatory manner).

154. Edmonson, 500 U.S. at 628.

155. See Arizona v. Fulminante, 499 U.S. 279, 309-10 (1991) (Rehnquist, CJ , for Court in part and dissenting in part).

156. This is precisely what the Court has said of the error of discrimination in the selection of grand jurors. See Fulminante, 499 U.S. at 310 (Rehnquist, C.J. for Cour in pant and dissenung in part). Vasquez. v. Hillery, 474 U.S. 254, 260-63 (1986). But see infra Section IVD (argung that reasoning of Hillen decision is unpersuasive and obsolete). 
This conclusion would be too prompt. For as I will show, ${ }^{157}$ Batson error, as Batson's proponents on the Court have defined it, cannot be structural error. This does not mean that Batson error is error of the other Fulminante sort: trial error, to which harmless error analysis does apply. Rather, Batson's proponents have defined the Batson norm in such a way that a Batson violation is absolutely harmless in every case. A Batson violation causes harm, of course, but it does not cause harm to any value that appellate reversal exists to protect. Thus the Court, presented with the question of whether to apply harmless error analysis to a Batson violation, would be driven to the odd position that Batson error should trigger not automatic reversal, but automatic affirmance. $^{\text {158 }}$

To see why this is so, consider who gets harmed by a Batson violation, and how. ${ }^{159}$ There are three possible victims of the discriminatory exercise of peremptory challenges: the defendant, ${ }^{160}$ the excluded juror, ${ }^{161}$ and the community. ${ }^{162}$ The Court has identified three distinct kinds of harm that one or more of these victims ${ }^{163}$ can suffer from jury discrimination. The first of these is the core equal protection harm of stigma. ${ }^{164}$ As the Court observed in its very first jury discrimination case, Strauder $v$. West Virginia, ${ }^{165}$ the exclusion of jurors on account of their race "is practically a brand upon them, affixed by the law, an assertion of their inferiority, and a stimulant to that race prejudice which is an impediment to securing to individuals of the race that equal justice which the law aims to secure to all others." 166 Where the defendant and the excluded juror are of the same minority race, they share in this stigmatic injury. ${ }^{167}$

157. See infra text accompanying notes 194-97.

158. When I say "automatic affirmance," I do not mean that all cases presenting Barson crror must be affirmed on appeal. Cases presenting Batson error might also present some other kind of error that does in fact warrant reversal. What I am suggesting is simply that a Batson violation-as currently defined-can never supply a reason for reversing a conviction.

159. For a careful student-written analysis of the possible types and victims of Barson error, sce David Zonana, Note, The Effect of Assumptions About Racial Bias on the Analysis of Batson's Three Harms and the Peremptory Challenge, 1994 ANN. SURV. AM. L. 203.

160. See Batson v. Kentucky, 476 U.S. 79, 85-87 (1986).

161. See id. at 87.

162. See id. at $87-88$.

163. Not every instance of jury discrimination will victimize all three of these individuals or groups. For example, in a $\mathrm{McC}$ Collum situation, where the defendant himself engages in illegal discrimination, the defendant may not be the one harmed. In this situation, the Court has made clear that the important interests at stake are those of the jurors and the community. See Georgia v. McCollum, 505 U.S. 42, 48-50 (1992).

164. See Paul Brest, The Supreme Court, 1975 Term-Foreword: In Defense of the Antidiscriminution Principle, 90 HARV. L. REV. 1, 8-11 (1976) (noting that courts heighten scrutiny of racial classifications because such classifications cause stigmatic harm to targeted groups); Charles R. Lawrence III, The Id, the Ego, and Equal Protection: Reckoning with Unconscious Racism, 39 STAN. L. REV. 317, 349-55 (1987).

165. 100 U.S. 303 (1879).

166. Id. at 308 .

167. See Batson v. Kentucky, 476 U.S. 79, 85-87 (1986). 
The second kind of injury that the Cour has identified is the injury to the excluded juror's equal protection right not to be excluded from a jury on account of race or gender. ${ }^{168}$ The Court has made clear that "[a]n individual juror does not have a right to sit on any particular petit jury, but he or she does possess the right not to be excluded from one on account of race." 169 This right has been the engine of much of the post-Batson development of the Batson norm. ${ }^{170}$

Finally, the third kind of injury that the Court has traced to jury discrimination is injury to the trial itself. This injury takes two related forms. On the one hand, the Court has suggested that Batson error directly undermines the defendant's right to a fair trial. ${ }^{17}$ On the other hand, the Court has said that Batson violations "undermine public confidence in the fairness of our system of justice."172 According to the Court, Batson error subverts both the actual fairness of the trial, in which the defendant has an interest, and the appearance of fairness, in which the community has an interest.

In sum, the Court has seen Batson error as causing some mix of stigmatic, participational, and fairness harms to defendants, excluded jurors, and the community. The trouble for Batson's proponents on the Court is that in a postFulminante world, none of the harms that Batson's proponents identify should trigger a rule of automatic reversal on appeal. Indeed, they should trigger precisely the opposite rule, that of automatic affirmance.

\section{A. Stigma}

Discriminatory peremptory challenges undoubtedly cause the very sort of stigmatic injury that the Court identified and condemned in Strauder. As the Strauder Court noted:

[It is difficult to] maintain[] that compelling a colored man to submit to a trial for his life by a jury drawn from a panel from which the State has expressly excluded every man of his race. because of color alone, however well qualified in other respects, is not a denial to him of equal legal protection. ${ }^{173}$

168. See, e.g., Batson, 476 U.S, at 87.

169. Powers v. Ohio, 499 U.S. 400,409 (1991).

170. The Court's decisions in McCollum, Edmonson, and Powers all rested pnmanly on the excluded juror's rights. See Georgia v. McCollum. 505 U.S. 42. $48-49$ (1992): Edmonson v Leesialle Conerele Co . 500 U.S. 614, 619 (1991); Powers, 499 U.S. at 409. According to Barbara Underuood, this is precisely as it should be. See Underwood, supra note 43, at 742-50 (arguing that jurors equal protection nghts provide proper basis for Batson and its progeny).

171. See Powers, 499 U.S. at 411-12; Barson, 476 U.S at 86-87

172. Batson, 476 U.S. at 87: see also MCCollum. 505 US at 49-50 (explaunng ham that Butson violations cause to public confidence in administration of justice. especially in rase-related cases)

173. Strauder v. West Virginia. 100 U.S. 303. 309 (1879) 
Particularly in a traditional Batson scenario, where the defendant and the excluded juror are of the same race or gender (as opposed to a Powers scenario, where they are not), both individuals suffer harm: the "brand[ing]"174 of their race or gender as unfair, incompetent, biased, or inferior.

This is a very real and a very cruel harm. The trouble is, it is the wrong kind. Appellate reversal does not exist to make the world a nicer place; it exists to guarantee the reliability of criminal verdicts. ${ }^{175}$ This is the central message of Fulminante, ${ }^{176}$ in which government agents caused a very real injury to an important value-indeed, a constitutional value, the defendant's Fifth Amendment right not to implicate himself. The Court acknowledged that this injury was serious, ${ }^{177}$ but it declined to deter that injury and bolster the underlying Fifth Amendment value with a rule of automatic reversal. What was true for the Fifth Amendment in Fulminante should also be true for the Fourteenth on a Batson appeal. Stigmatic injury is injury to the central value in the Equal Protection Clause of the Fourteenth Amendment, but no matter how serious that injury may be, the remedy of appellate reversal does not exist to deter it. ${ }^{178}$

\section{B. Participation in the Criminal Justice System}

Precisely the same is true of the second type of Batson harm-injury to the excluded juror's right to equal participation in the criminal justice system. The Court has waxed eloquent about this right, quoting de Tocqueville for the view that the jury "invests each citizen with a kind of magistracy; it makes them all feel the duties which they are bound to discharge towards society; and the part which they take in the Government." ${ }^{179}$ Batson violations, according

174. Id. at 308 .

175. See supra notes $108-47$ and accompanying text (explaining development of Court's view that only non-harmless error is reversible).

176. Arizona v. Fulminante, 499 U.S. 279 (1991).

177. See id. at 311-12 (Rehnquist, C.J., for Court in part and dissenting in part).

178. I am here describing how the rule of appellate reversal appears to operate in the post-Fulmintume world. I am not making a normative argument that appellate reversal ought not be available to remedy the stigmatic injury occasioned by racial discrimination in jury selection. In my view, Fulminante was a mistake; the appellate process ought to protect more values than just verdict reliability. Neverthcless, the Court decided otherwise in Fulminante, and we must now assess the impact of that case's narrowing of the function of appellate reversal on all varieties of trial error, including Batson error.

179. Powers v. Ohio, 499 U.S. 400, 406-07 (1991) (quoting ALEXIS DE TOCQUEvILLE, DemocraCY IN AMERICA 334-37 (Schocken ed., Ist ed. 1961)). The Powers Court also noted that the jury system "“postulates a conscious duty of participation in the machinery of justice," id. at 406 (quoting Balzac $v$. Porto Rico, 258 U.S. 298, 310 (1922)), and that "[j]ury service preserves the democratic element of the law," id. at 407. 
to the Court, "foreclose[] a significant opportunity [for the excluded jurors] to participate in civic life," and thereby violate the Equal Protection Clause. ${ }^{180}$

And there, again, is the rub: Convictions are not reversed to deter violations of the Equal Protection Clause. ${ }^{181}$ From the standpoint of an appellate court reviewing a criminal conviction in a post-Fulminante world, a prosecutor's illegal courtroom decision to dismiss a juror on account of race or gender should have the same consequences for the defendant as that prosecutor's illegal office decision to fire a secretary on account of race or gender. In both instances, the prosecutor has offended deep and important equal protection values. But when the appellate cour reviews a criminal conviction, it does not police those values for their own sake; it polices the reliability of the verdict. The harm to the excluded juror's equal protection rights thus should not result in a rule of automatic reversal of the defendant's conviction; it should result in the opposite.

\section{The Fairness of the Trial-Actual and Perceived}

As noted above, the Court has also condemned Batson error for damaging the defendant's right to a fair trial and the community's interest in a criminal justice system that appears to run fairly. ${ }^{182}$ Of the several kinds of injury that the Court has traced to Batson, these injuries would seem to provide the Court with the sturdiest foundation for concluding that Batson error is Fulminantestyle "structural" error subject to a rule of automatic reversal. Yet the sturdiness of this foundation is illusory: Batson and its progeny simply do not support the conclusion that jury discrimination undermines the fairness of trials. Indeed, the cases support precisely the opposite conclusion.

\section{The Actual Faimess of the Trial}

From the outset, the Court has been cavalier in asserting, yet timid in explaining, the fair trial impact of Batson error. In Batson itself, the Court said briefly that the fair trial harm of jury discrimination is that it "denies [the defendant] the protection that a trial by jury is intended to secure."183 Because the jury is supposed to be "'.indifferently chosen,"'1st jury discrimination violates "the very idea of a jury." 185 This rather cryptic and

180. See id. at 409. See generally Underwood, supra note 43, at 745-47 (elaboratıng on particıpatıonal injury caused by exclusion from jury service).

181. See infra note 196.

182. See supra notes $171-72$ and accompanying text.

183. Batson v. Kentucky, 476 U.S. 79. 86 (1986).

184. Id. at 87 (quoting 4 WILLAM BLACKSTONe. Commentaries - 350)

185. Id. at 86. Of course, if this is the true harm that Batson error causes to the faimess of tnals, then the Court seems to have lost its nerve just four years later in Hollond v: Illinots, when it held that the Sixth Amendment's guarantee of an "imparial jury" does not forbid discrimination in the selection of petit junes. 
undeveloped suggestion in Batson is the closest that the Court has ever come to identifying any real impact that Batson error has on the actual fairness of trials. ${ }^{186}$ In its cases following and extending Batson, the Court has shied away from the claim that jury discrimination actually makes trials unfair, instead retreating to vague assertions about the appearance of fairness. ${ }^{187}$ In Powers v. Ohio, ${ }^{188}$ for example, the Court had to establish that a white defendant suffered cognizable injury from the exclusion of black jurors in order to hold that the defendant had standing to lodge a Batson objection. This was the moment for the Court to state explicitly how racially discriminatory peremptories actually damage the fairness of criminal trials. Yet the Court could muster nothing more specific than this: "[R]acial discrimination in the selection of jurors 'casts doubt on the integrity of the judicial process,' ... places the fairness of a criminal proceeding in doubt.... [and] invites cynicism respecting the jury's neutrality and its obligation to adhere to the law."189 "Placing in doubt" and "inviting cynicism" are defects in the appearance, not the reality, of fairness. Thus, in Powers, what had originally been two discrete forms of injury - injury to the defendant's right to a fair trial and injury to the community's interest in a process that appears fair-collapsed into the weaker of the two injuries, the injury to appearance.

Why has the Court been so reluctant to describe the fair trial impact of Batson error? The reason is simple: The Batson cases themselves say that there is no such impact. As explained above, ${ }^{190}$ the Court in Batson and its progeny has continually and stridently rejected the theory of difference-the theory that an attorney might rationally infer something about a prospective juror's perspective from his or her group affiliation. Race and gender are not merely illegal but false proxies for viewpoint. This means that when a black woman is removed from the jury because of her race and gender, and is

See Holland v. Illinois, 493 U.S. 474, 478, 487 (1990). For a discussion of Holland, see infra Section VI.B.

186. The Court's unease in stating and defining the fair trial impact of Batson error may stem from the fact that Batson and its progeny are equal protection cases. In using equal protection to guarantec fair trials, the Court has pressed the Equal Protection Clause into a criminal-process service to which it is not obviously suited. See infra notes $246-47$ and accompanying text. The more obvious textual anchor for an effort to ensure full representation of the community on the petit jury is the Sixth Amendment's guarantec of an impartial jury in all criminal cases. See U.S. CONST. amend. VI. The Court, however, has not interpreted that language in this way. See Holland v. Illinois, 493 U.S. 474 (1990), discussed infra at text accompanying notes 272-303.

187. In Allen v. Hardy, 478 U.S. 255 (1986) (per curiam), the Court addressed whether Batson should apply retroactively to convictions that had become final before Batson was decided. Part of the Court's inquiry was whether Batson had been "'designed to enhance the accuracy of criminal trials." Id. at 259 (quoting Solem v. Stumes, 465 U.S. 638, 643 (1984)). On this score, the Allen Court merely noted that "the rule in Batson may have some bearing on the truthfinding function of a criminal trial." Id. at 259 (emphasis added). But the Court much more confidently asserted that Batson "strengthens public confidence in the administration of justice." Id.

188. Powers v. Ohio, 499 U.S. 400 (199I).

189. Id. at $411-12$ (citation omitted).

190. See supra Part II. 
replaced by a white man, nothing is lost. ${ }^{191}$ The new juror is presumptively as fair and impartial as the one who was excused. As Justice Scalia objected in his dissent in J.E.B., this approach views jurors as "fungible." 192 A Batson violation by definition has no impact on the jury or on the quality of the jury's deliberations. In all important ways, Batson error leaves the jury unchanged. ${ }^{193}$

Fulminante's concept of "structural error," moreover, is of no help to the Court. A Batson violation is admittedly a "structural defect[] in the constitution of the trial mechanism," which is one of Fulminante's criteria for structural error. ${ }^{194}$ But this structural defect is harmless in every case. True structural error, which warrants a rule of automatic reversal under Fulminante, not only alters the constitution of the trial mechanism, but also "obviously affect[s]" the "entire conduct of the trial" from start to finish. ${ }^{195}$ In other words, structural error is error whose damaging effect on the reliability of verdicts we cannot measure from a cold record but can simply presume. By rejecting the theory of difference, Batson forecloses exactly that presumption. ${ }^{10}$ Having defined away the only possible harm that could qualify a Batson violation as structural error, Batson's proponents are left with only one odd and counterintuitive option: They must ignore the violation and affirm the conviction.

\section{The Perceived Fairness of the Trial}

Batson's champions on the Court cannot escape this conundrum by asserting that a rule of automatic reversal is necessary to protect the community's (as distinct from the defendant's) interest in the appearance (as distinct from the reality) of a fair trial. In the first place, Fulminante tells us quite clearly that appellate reversal is reserved for real impairments to the

191. For a suggestion that this odd result flows from Sirauder v: West Virginia. 100 U.S. 303 (1879). see Zonana, supra note 159, at 209-10.

192. J.E.B. v. Alabama ex rel. T.B., 114 S. Cl. 1419. 1437 (1991) (Sealıa, J , dissenung)

193. I should make clear here that $I$ am not arguing that this conclusion about the fasr tral harm of Batson error is correct. In fact, I make the opposite claim in Part VI. I am arguing here only that this counterintuitive conclusion about the fair trial harm of Batson error flows from the Batson Court's premises, taken together with the Fulminante approach to appellate remedies.

194. See Arizona v. Fulminante. 499 U.S. 279. 309 (1991)

195. Id. at 309-10.

196. Indeed, it does more: it seems to undermine Strauder itself. Sirauder was a direet appeal from a criminal conviction obtained from a jury from which all blacks had been excluded by law The Court automatically reversed the conviction, without evaluatung the harmfulness of the equal protection violation to the reliability of the verdict. See Strauder v. West Virginıl. 100 U.S. 303.312 (1879)

Fulminante, of course, requires actual or presumed harm to the reliability of the verdict as a condition of appellate reversal. Batson's proponents on the Coun suggest that there is. by definition, no such ham. Under current law, then, it would seem (startlingly) that Sirauder was wrongly decided on the question of remedy - that the Court wrongly deployed a rule of automatic reversal to police an equal protection norm that had nothing to do with the factual reliability of verdiets. The sime would be true of Whutus v Georgus. 385 U.S. 545 (1967); Hernandez v. Texas, 347 U.S. 475 (1954); and Palron v Mississippi, 332 U.S. 463 (1947), in all of which the Cour reversed convictions to punish equal protection violations in jury selection. 
value of verdict reliability, not speculative ones. While the public might believe that jury discrimination makes verdicts unreliable, the Court's rejection of the theory of difference in the Batson line of cases means that Batson's proponents think the public is simply wrong. Nowhere has the Court suggested that reversal is appropriate simply because the public mistakenly believes that a particular error impugns the reliability of verdicts. More fundamentally, nowhere has the Court suggested that appellate reversal serves the value of appearance, or the value of public trust and confidence in the criminal justice system. Coerced confessions surely undermine public confidence in that system, yet the Fulminante Court never hinted that the public's interest in an honest and fair system deserved protection through a rule of automatic appellate reversal.

Secondly, even if the Court could employ an appellate remedy to protect the interests of the community without violating Fulminante, this does not imply that a rule of reversal would be appropriate. The community interest that the Court identifies in Batson and its progeny is the community's disapproval of racial prejudice in the administration of justice. ${ }^{197}$ This is undoubtedly one important interest at issue when an appellate court reviews a Batson violation, but it is not the only one. Does not the community also have a very strong interest in seeing criminals punished? And if jury discrimination has no impact on the reliability of verdicts, as the Court's reasoning implies, does not the community have an interest in ensuring that the correctly convicted criminal not receive the windfall of a reversal of his conviction? In other words, to the extent that the community's interests should determine the appropriate appellate remedy, there are more of them than the Court recognizes, and they do not all point to a rule of reversal.

\section{The Curious Persistence of Vasquez v. Hillery}

Some courts and commentators have looked to the Court's 1986 opinion in Vasquez $v$. Hillery ${ }^{198}$ as proof that Batson error would require a rule of automatic reversal. ${ }^{199}$ However, Hillery and a virtually identical case that preceded it by about six years, Rose $v$. Mitchell, ${ }^{200}$ actually show just the opposite. In both Mitchell and Hillery, the petitioners sought relief for the intentional race discrimination in the selection of the grand juries that indicted them. In Mitchell, the discrimination had allegedly infected the selection of a

197. See, e.g., Batson v. Kentucky, 476 U.S. 79, 87 (1986).

198. 474 U.S. 254 (1986).

199. See Rosa v. Peters, 36 F.3d 625, 634 n.17 (7th Cir. 1994); Blair v. Armontrout, 976 F.2d 1130 , 1143 n.2 (8th Cir. 1992) (Heaney, J., concurring in part and dissenting in part); United States v. Thompson, 827 F.2d 1254, 1261 (9th Cir. 1987); Batiste v. State, 888 S.W.2d 9, 13-14 (Tex. Crim. App. 1994); Herman, supra note 15 , at 1831 n.98.

200. 443 U.S. 545 (1979). 
grand jury foreman; in Hillery, the discrimination had infected the selection of the entire grand jury. In neither case, however, did the petitioner suggest that his trial had been unfair or that the petit jury that convicted him had been unlawfully selected. As might be expected, the State argued in each case that the lawfully obtained conviction at trial cured any equal protection error at the grand jury stage. In both instances, the Court rejected the State's harmless error argument.

The Court's rationale shifted tellingly in the years between the two cases. In Mitchell, the Court's reason for choosing a rule of automatic reversal was the obvious one: "Because discrimination on the basis of race in the selection of members of a grand jury... strikes at the fundamental values of our judicial system and our society as a whole," ${ }^{201}$ a rule of automatic reversal was necessary to enforce "the strong policy the Court consistently has recognized of combatting racial discrimination in the administration of justice." ${ }^{202}$ There was no pretense in Mitchell that racial discrimination in the selection of grand jurors required a rule of automatic reversal because that discrimination seriously impugned the reliability of the petit jury's ultimate conviction. The Court simply recognized automatic reversal to be the best possible deterrent of equal protection violations embedded in the charging process.

Justice Marshall's opinion for the Court in Hillery, by contrast, is almost nothing but pretense. By 1986, it was only barely tenable for the Court to suggest that a conviction should be reversed to deter an equal protection violation that did not have concrete impact on the reliability of the conviction. Fulminante had not yet been decided, but the writing was plainly on the wall. ${ }^{203}$ Justice Marshall therefore mentioned the outmoded reasoning of Mitchell only in passing. ${ }^{204}$ Instead, he attempted to show that discrimination in the selection of grand jurors actually has a concrete impact on the reliability of verdicts. His argument was that a grand jury selected without regard to race might choose to indict a defendant on lesser charges or fewer counts or might choose not to indict at all. ${ }^{205}$ To any criminal practitioner, this theory of harm is unpersuasive. Perhaps grand juries were once the independent bodies that Justice Marshall described, but they surely are not now. Except in the rarest of cases, grand juries vote "yea" or "nay" on an indictment that has been framed by the prosecutor, and almost invariably vote "yea." It is often said that a modern grand jury would, if asked by the prosecutor, vote to indict a ham

201. Id. at 556.

202. Id. at 558 .

203. See, e.g., Delaware v. Van Arsdall. 475 U.S 673. 681 (1986) (recogniang "pnnciple that the central purpose of a criminal trial is to decide the factual question of the defendant's guitt or innocence"). see also Stacy \& Dayton, supra note 109, at 80-88 (discussing increasing use of hamless constitutionai error doctrine).

204. See Vasquez v. Hillery, 474 U.S. 254, 264 (1985)

205. See id. at 263. 
sandwich. ${ }^{206}$ Justice Marshall's depiction of the grand jury as a body exercising independent will over the charging decision is, at very best, an anachronism, and at worst, pure makeweight.

The Hillery opinion speaks volumes about the Court's redefinition of the remedy of appellate reversal. Justice Marshall labored mightily to produce a reason why grand jury discrimination might affect the accuracy of a subsequent conviction, but the strain is obvious. In fact, it is not even clear that Justice Marshall attracted five votes to the position that grand jury discrimination is automatically reversible in every case: Justice O'Connor concurred only in the judgment in Hillery, ${ }^{207}$ and Justice White pointedly declined to join the key paragraph of Justice Marshall's opinion that established the rule of per se reversal. ${ }^{208}$

In the end, Hillery may best be understood not as an opinion about harm to the reliability of verdicts, but as a last gasp from the group of Justices who opposed the Court's growing fixation on the reliability of verdicts. After all, the majority camp in Hillery was the dissenting camp in Fulminante, almost to a person. ${ }^{209}$ Of the two opinions in Hillery and Mitchell, Mitchell is the more direct and more honest-and it is plainly foreclosed by the reasoning of Fulminante. Whatever the conceptual validity of Hillery when it was decided, it is now a relic from a bygone era. ${ }^{210}$

The Justices who brought us the Batson rule thus find themselves in a very odd contradiction. Jury discrimination, they tell us, is corrosive, offensive, irrational, illegal-yet absolutely harmless in every case. The depth of this contradiction is a good hint that something is amiss in the Court's response to the discriminatory use of peremptory challenges.

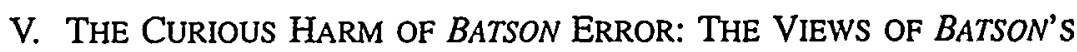 OPPONENTS}

One might expect that the Justices who have opposed the creation and extension of the Batson norm would criticize Batson's proponents for this central contradiction on the nature of the fair trial injury caused by jury

206. See, e.g., Akhil Reed Amar, Reinventing Juries: Ten Suggested Reforms, 28 U.C. DAvIS L. REv. 1169, 1175 (1995); Andrew D. Leipold, Why Grand Juries Do Not (and Cannot) Protect the Accused, 80 CORNELL L. REV. 260, 263 (1995).

207. See Hillery, 474 U.S. at 266-67 (O'Connor, J., concurring in judgment).

208. See id. at 264 n.6.

209. Justice Brennan had retired by the time of Fulminante.

210. I mean here that Hillery is conceptually obsolete, not that it is no longer good law. In Fulminunie, Chief Justice Rehnquist cited the error in Hillery as one of the few structural errors that still trigger automatic reversal. See Arizona v. Fulminante, 499 U.S. 279, 310 (1991) (Rehnquist, C.J., for Court in part and dissenting in part). This citation should not, however, be taken as an endorsement of Hillery's reasoning; the Chief Justice was, after all, a dissenter in Hillery. See Hillery, 474 U.S. at 267 (Powell, J., joined by Burger, C.J. \& Rehnquist, J., dissenting). At most, the citation simply reflects the Chief Justice's deference to precedent. 
discrimination. In a limited way, they have: Justice Scalia, in his J.E.B. dissent, pointed out that if male and female jurors truly are fungible, then striking them on account of their gender can harm only the jurors themselves, not the litigants. ${ }^{211}$ Yet Batson's opponents on the Court have mired themselves in a contradiction or two of their own making. The most obvious of these is the precise mirror image of the one plaguing Batson's defenders. Batson's proponents are unable to point to the harm that jury discrimination causes to the reliability of criminal verdicts, yet they nonetheless speak of it as harmful. Batson's opponents, on the other hand, might easily point to the harm that jury discrimination causes to the reliability of criminal verdicts, yet they speak of it as harmless.

As noted earlier, ${ }^{212}$ an error is "structural" (and thus per se reversible) if it is a flaw in the constitution of the trial mechanism, and obviously harms the reliability of the verdict, even though a reviewing court cannot pinpoint in the record exactly when the harm occurred. The proponents of the Batson rule run into difficulty on the second of these criteria; as they have defined the Batson norm, it is simply impossible to presume any injury to the reliability of the verdict.

The opponents of the Batson norm have no trouble at all supplying this second step of the analysis. From the start, they have embraced rather than rejected the theory of difference: They have acknowledged that it is at least minimally rational for an attorney to infer something about a prospective juror's viewpoint from his or her race or gender, and that jurors of different races and genders are not "fungible." ${ }^{13}$ While Batson's proponents are forced to assert that replacing one juror with another of a different race or the other gender has no impact on the jury or the quality of its deliberations, Batson's opponents can comfortably suggest just the opposite. For the purposes of choosing an appellate remedy, this is crucial: Batson error becomes not just a defect in the composition of the trial mechanism, but a defect that makes a difference. Thus it is Batson's critics, not its champions, who would be able

211. See J.E.B. v. Alabama ex rel. T.B., 114 S. Ct. 1419. 1437 (1994) (Scalia. J . dissenung) (joined by Rehnquist, C.J. \& Thomas, J.) ("But if men and women jurors are (as the Coun thinks) fungible. then the only arguable injury from the prosecutor's 'impermissible' use of male sex as the basis for his peremptories is injury to the stricken juror, not to the defendant.")

212. See supra notes $126-31$ and accompanying text.

213. J.E.B., 114 S. Ct. at 1437 (Scalia, J.. dissentung); see also ud. at 1432 (O'Connor. J . concumng) ("We know that like race, gender matters."): id. al 1436 (Scalıa. J . dissenung) (expressing "personallj" belief that a juror's gender has some statistically signıficant prediclive value in certan types of cases). Georgia v. McCollum, 505 U.S. 42, 61 (1992) (Thomas. J.. concurnng in judgment) (noting "common experience and common sense" suggest link betwoen juror race and inal outcome in al leasl some cases). Batson v. Kentucky, 476 U.S. 79, 121 (1986) (Burger, C.J.. dissentıng) (endorsing vieu that "certaun classes of people" have statistically demonstrable "predispositions"): id. at 138-39 (Rehnquist. J. dissenung) (accepting group affiliation as "'proxy' for potentıal juror partialıy")

Justice $O^{\prime}$ Connor, of course, is not technically an opponent of Butson or its extenston to at least certain other contexts. See supra note 75 . She does. however, share with Butson's opponents the view that a prospective juror's race or gender is a rational predictor of his or her perspective See JEB. $114 \mathrm{~S} \mathrm{Cl}$ at 1431-32 ( $0^{\circ}$ Connor, J., concurring). 
to define Batson violations as true "structural error," and who might therefore be expected to favor a rule of automatic reversal.

To compound the contradiction, it appears that Batson's critics would not in fact favor such a rule. Their view of whether jury discrimination would be harmless error is difficult to tease out of the cases; their ultimate position, after all, is that the discriminatory use of peremptory challenges is not any sort of error. They have always maintained that when peremptory strikes exercised on the basis of race or gender fall upon all races and both genders equally, they do not violate anyone's equal protection rights. ${ }^{214}$ They have also maintained that such strikes, when exercised adversarially by both parties, are useful tools for eliminating the extremes of bias from both ideological ends of the jury, thereby enhancing the Sixth Amendment value of jury impartiality. ${ }^{215}$ Yet at rare moments, in order to decide cases, they must (or, for the sake of argument, do) assume that peremptories based on race or gender violate the Constitution. And they profess to see no harm.

The position that race- or gender-based peremptories do not amount to reversible error began to emerge just two months after Batson was decided. In Allen v. Hardy, ${ }^{216}$ the Court was called upon to decide whether its newly minted Batson rule should be applied retroactively to cases that had become final before Batson was decided. In a brief per curiam opinion, the Court held that it should not. ${ }^{217}$ It is impossible to know who wrote the Allen opinion, but it is certain that the two Batson dissenters, then-Justice Rehnquist and Chief Justice Burger, were among the six Justices in the Allen majority. ${ }^{218}$ That majority could say nothing more of Batson's rule than that it "may have some bearing on ... truthfinding." ${ }^{\text {"219 }}$ But the majority "[could not] say that the ... rule has such a fundamental impact on the integrity of factfinding as to compel retroactive application." ${ }^{220}$ With the ink barely dry on their Batson dissents-dissents in which both Justices embraced the theory of difference ${ }^{221}-$ Batson's two opponents on the Court assumed that Batson

214. See J.E.B., 114 S. Ct. at 1437 (Scalia, J., dissenting); Powers v. Ohio, 499 U.S. 400, 423-24 (1991) (Scalia, J., dissenting); Batson, 476 U.S. at 137-38 (Rehnquist, J., dissenting).

215. See Edmonson v. Leesville Concrete Co., 500 U.S. 614, 644 (1991) (Scalia, J., dissenting) (arguing that peremptories can sometimes assure racially diverse jury); Powers, 499 U.S. at 426-27 (Scalia, J., dissenting) (noting that Holland suggested that race-based peremptories may increase fairness); Holland v. Illinois, 493 U.S. 474, 481, 483-84 (1990); Batson, 476 U.S. at 139 (Rehnquist, J., dissenting).

216. 478 U.S. 255 (1986).

217. See id. at 259-61.

218. Justices Marshall and Stevens, both in the majority in Batson, dissented in Allen. See id. at 261-64. Justice Blackmun, also a member of the Batson majority, objected to the summary disposition in Allen, and would have set the case for oral argument. See id. at 261 (Blackmun, J., dissenting).

219. Id. at 259.

220. Id.

221. See Batson v. Kentucky, 476 U.S. 79, 121 (1986) (Burger, C.J., dissenting) (suggesting statistical basis underlying use of race as proxy for bias); id. at 138-39 (Rehnquist, J., dissenting) (suggesting that age, race, and occupation as " "proxy' for potential juror partiality" can be useful for climinating biased jurors). 
error was indeed error, yet saw no significant harm to the reliability of verdicts. 222

The position emerged in sharper relief a few years later in Teague $v$ Lane, ${ }^{223}$ a habeas corpus case. In Teague, the petitioner was a black man who had been convicted of a number of violent crimes by an all-white jury in state court. ${ }^{224}$ The trial prosecutor had used all ten of his peremptory challenges against black prospective jurors. ${ }^{23}$ Because his conviction had become final two and a half years before Batson was decided, the defendant was unable to avail himself of its benefit in his habeas petition. ${ }^{326}$ Instead, he urged the Supreme Court to create (and apply to his case) a new Batsonlike rule to enforce the Sixth Amendment's requirement of a jury that represents the community. ${ }^{227}$ This was, of course, precisely the Sixth Amendment argument that a bare majority of the Court would reject on its merits a year later in Holland $v$. Illinois. ${ }^{228}$

The Teague plurality ${ }^{229}$ did not reach the merits of the petitioner's Sixth Amendment argument. Instead, it held that because the petitioner's Sixth Amendment argument, if adopted, would "break[] new ground," it was not appropriate for the Court to announce such a rule in a habeas case. ${ }^{\text {?w }}$ The plurality did note that there were certain narrow exceptions to the principle against announcing new rules of constitutional law in habeas cases. One such exception applies when the new rule that the habeas petitioner seeks is one "without which the likelihood of an accurate conviction is seriously diminished."231 But the plurality simply did not see the petitioner's proposed Sixth Amendment rule as falling into that category. The plurality assumed, for the sake of argument, that the Sixth Amendment did in fact require a Batsonlike rule to insure that the seated petit jury did not purposely misrepresent the community, but was nonetheless quite confident that a court's failure to follow such a rule would not "seriously diminish the likelihood of obtaining an accurate conviction." ${ }^{, 32}$ As in Allen v. Hardy, a group of Justices including Batson's most vociferous opponents accepted the Batson rule (or, in Teague,

222. Justice O'Connor was also in the Allen majonty. She. houever. had jouned the Court's opınon in Batson. See Batson, 476 U.S. at 111 (O'Connor. J., concumng)

223. 489 U.S. 288 (1989).

224. See id. at 292-93.

225. See id. at 293.

226. See id. at $295-96$.

227. See id. at 299, 314-15 (plurality opinion). But see ad at 340-42 (Brennan. J . dissentung) (notung

Teague's Sixth Amendment claim seeks only "procedures that allow a fatr posstbilin for the jun to fetlect a cross-section of the community").

228. 493 U.S. 474,478 (1990) (5-4 decision). For a discussion of the Court's opinion in Holland, see infra Section VI.B.

229. The Teague plurality consisted of Chef Justuce Rehnquist, and Justices O'Connor. Stalıa, and Kennedy. See Teague, 489 U.S. at 292.

230. See id. at 301 .

231. Id. at 313 .

232. Id. at 315 . 
one just like it) on its own terms, imagined that the rule had been violated, yet saw no significant harm.

The Batson opponents' apparent unwillingness to honor their commitment to the theory of difference surfaced again in Justice Scalia's dissent in J.E.B. ${ }^{233}$ There, the State used nine of its ten peremptory strikes to remove men from the jury, with the result that the jury actually seated to hear the paternity suit was all female. ${ }^{234}$ Justice Scalia, joined by Chief Justice Rehnquist and Justice Thomas, dissented from the Court's decision to extend the Batson norm to gender discrimination. ${ }^{235}$ Chiding the majority for its "fervent defense of the proposition il n'y a pas de différence entre les hommes et les femmes," ${ }^{236}$ he pointed out that a consequence of the majority's rejection of the theory of difference was to make all jurors "fungible," and thereby to eliminate any chance that a litigant might suffer harm from Batson error. ${ }^{237} \mathrm{He}$ continued his thrust: "Not only has petitioner, by implication of the Court's own reasoning, suffered no harm, but the scientific evidence presented at trial established petitioner's paternity with $99.92 \%$ accuracy.",238 This meant for Justice Scalia that "[i]nsofar as [the defendant] is concerned, this is a case of harmless error if there ever was one."239

It is important to recognize that in this passage of the opinion, Justice Scalia was not arguing his own views of the harms of discriminatory peremptory challenges. In Justice Scalia's view, it should be unnecessary even to address the question of whether the discriminatory exercise of peremptory challenges could ever be harmless error. For him, such challenges are not "error" of any kind. They are instead legitimate tools that assist in seating an impartial jury. ${ }^{240}$ Rather, he was assuming, for the sake of argument, the J.E.B. majority's premise that Batson error is in fact error, and was trying to refute it on its own terms. Any Batson error in this case, he claimed, was necessarily harmless because first, in the majority's view, jurors are fungible, and second, in any event, the evidence of the defendant's paternity was overwhelming.

This second move was the revealing one, for it seems precluded by a commitment to the theory of difference. Justice Scalia does not think that jurors are fungible. For Justice Scalia, it is an "undeniable reality . . . that all groups tend to have particular sympathies and hostilities." ${ }^{241}$ He therefore

233. See J.E.B v. Alabama ex rel. T.B., 114 S. Ct. 1419 (1994).

234. See id. at 1422 .

235. See id. at 1436-39 (Scalia, J., dissenting).

236. $\mathrm{Id}$. at 1436 (Scalia, J., dissenting).

237. Id. at 1437 (Scalia, J., dissenting).

238. $J d$. (Scalia, J., dissenting).

239. Id. (Scalia, J., dissenting).

240. See, e.g., id. at 1438-39 (Scalia, J., dissenting) ("The biases that go along with group characteristics tend to be biases that the juror himself does not perceive, so that it is no use asking about them."); Powers v. Ohio, 499 U.S. 400, 423-24 (1991) (Scalia, J., dissenting).

241. Powers, 499 U.S. at 424 (Scalia, J., dissenting). 
should not be able to assume that Batson error is indeed error, as he does in this passage from his J.E.B. dissent, and simultaneously point to the weight of the evidence as proof that such an error is harmless. If it is in fact error for an attorney to strike a juror from the jury panel on account of race or gender, and if that juror's race or gender suggests a distinctive perspective, then that error must be structural. ${ }^{242}$ Even if the paternity test were one hundred percent accurate, that would not matter. The conviction should still be reversed. This should have been apparent to Justice Scalia, in light of the "vive la differrence?" tone of his J.E.B. dissent. Yet Justice Scalia, and the Batson opponents for whom he wrote, seemed eager to conclude that Barson error-even assuming that it was in fact error-could nonetheless be harmless to the reliability of the verdict. $^{243}$

\section{BuIlding a BetTer BATSON: The SiXTH AMENDMENT AND the REPRESENTATIVE JURY}

When it comes to identifying the appropriate appellate remedy for Batson error, there is more than enough contradiction to go around. Yet the ease with which Batson's opponents might find Baison error to be structural suggests an easy way for Batson's proponents to resolve the contradiction in their own views: They could simply abandon their resistance to the theory of difference. It has never been entirely clear why Batson's proponents have clung so tenaciously to the view that race and gender are not just illegal but flatly irrational proxies for viewpoint. They certainly need not maintain this view in order to condemn race- and gender-based peremptories as illegal; they could

242. Such an error could not conceivably be labelled tral error and then subjected to harnless error analysis. In Sullivan v. Louisiana, 508 U.S. 275 (1993). a constutuonally defectuve instruction on reasonable doubt deprived the murder defendant of his nght to tnal by a "jury" of the sort guaranteed by the Sixth Amendment. See id. at 276-78. Justice Scalia, wriung for a unamumous Coun. easily brushed aside the State's claim that the denial of the defendant's right to a jury that met the Sir h Amendment's standards was amenable to harmless error analysis. See id. at 278-81. He did so in the face of strong evidence of the defendant's guilt. See State v. Sullivan, 596 So. 2d 177, 180-81, 186 (L. 1992) (noung evidence of defendant's guilt included inculpatory confession from immunized accomplice, eyewitness identıfications. and expert ballistics testimony linking bullets removed from vicum's body and from cnme seene to gun found in apartment where defendant had gone after crime), rev'd sub nom. Sullivan v. Loutsiana, 508 U $S$ 275 (1993). Justice Scalia insisted that it was senseless to inquire whether a real "jury" of the kind guaranteed by the Sixth Amendment would undoubiedly have convicted the defendant on such evidence: the point was that the evidence had never been reviewed by such a jury in the first place because of a faulty reasonable doubt instruction. See Sullivan. $113 \mathrm{~S}$. Ct. at 279-80 It stands to reason that harmless error review would be equally inappropriate in other circumstances where a defendant is denied the "jury" guaranteed by the Sixth Amendment. Cf. Batson v. Kentucky, 476 U S. 79. 86 (1986) (holding that jury discrimination violates "[t]he very idea of a jury").

243. See Powers, 499 U.S. at 431 (Scalia, J., joined by Rehnquist. C.J. dissenung) ("Even if I agreed that the exercise of peremptory strikes constitutes unlawful discrimination . . I Hould not understand why the release of a convicted murderer who has not been harmed by those strikes is an appropnate remedy "). Duren v. Missouri, 439 U.S. 357, 373 n.* (1979) (Rehnquist, J . dissentung) ("The reversal of concededly fair convictions returned by concededly impartal junes is, to say the least, an imalional means of vindicating the equal protection rights of those unconstitutionally excluded from jury service.") 
easily maintain that an attorney acts rationally by making these sorts of challenges, but that values of antidiscrimination in the Constitution make this rational behavior illegal. This is precisely the position Justice O'Connor took in her concurring opinion in J.E.B. ${ }^{244}$ Thus Batson's supporters could concede that the opposing camp is right, at least in part: Race and gender are rational, even if imperfect, proxies for viewpoint. This concession would supply them with the missing piece in their "structural error" analysis, and would permit them to establish a rule of automatic reversal for Batson violations. ${ }^{245}$

Yet the rule of automatic reversal would not be an entirely satisfactory solution. It would perpetuate the oddity of conscripting the Equal Protection Clause for the task of regulating the faimess of criminal trials and the accuracy of jury verdicts, when there are a number of other protections in the Bill of Rights-the most obvious being the Sixth Amendment's Jury Clause ${ }^{246}$ - that seem more obviously suited to these ends. The Equal Protection Clause handles well the participational injury suffered by the wrongfully excluded jurors and the stigmatic injury suffered by minority jurors and defendants. But it takes a fairly creative gloss on equal protection to conscript it as a fair trial guarantee, a gloss that the Court has not supplied. ${ }^{247}$

There is, however, another solution to the problem of the fair trial harm caused by Batson error: relocate the fair trial harm from the Fourteenth Amendment's Equal Protection Clause to the Sixth Amendment's ${ }^{248}$ jury trial

244. See J.E.B. v. Alabama ex rel. T.B., 114 S. Ct. 1419, 1431-32 (1994) (O'Connor, J., concurring); see also Brown v. North Carolina, 479 U.S. 940, 940-42 (1986) (O'Connor, J., concurring in denial of certiorari).

245. Of course, if Batson's proponents were now to embrace the theory of difference, this would place them at odds with the overall direction in which the Court appears to be heading on the issue of racial difference. See Adarand Constructors, Inc. v. Pena, 115 S. Ct. 2097, 2119 (1995) (Scalia, J., concurring in part and concurring in judgment) ("In the eyes of government, we are just one race here. It is American."); Miller v. Johnson, 115 S. Ct. 2475, 2494 (1995); Shaw v. Reno, 113 S. Ct. 2816, 2827 (1993). See generally Jeffrey Rosen, The Color-Blind Court, NEW REPUBLIC, July 31, 1995, at 19 (explaining and critiquing several decisions of Supreme Court's 1994 Term that revealed emerging commitment to absolute colorblindness in constitutional adjudication).

246. See U.S. CONST. amend. VI ("In all criminal prosecutions, the accused shall enjoy the right to a speedy and public trial, by an impartial jury of the State and district wherein the crime shall have been committed, which district shall have been previously ascertained by law ....").

247. The Court has used the Equal Protection Clause to guarantee some minimal fairness in post-trial proceedings - on appeals and collateral review. See, e.g., Douglas v. California, 372 U.S. 353, 357-58 (1963) (holding that indigent defendants have right to appointed counsel on first direct appeal taken as of right); Griffin v. Illinois, 351 U.S. 12, 18 (1956) (holding that indigent defendants have right to trial transcript at public expense where necessary on direct appeal). Even in these cases, the Court did not use the Equal Protection Clause to gauge the actual fairness of the substance of the appellate or collateral review. Rather, the Court simply used the Equal Protection Clause to insist on equal access to this sort of review, regardless of wealth.

248. Others have pointed to the Sixth Amendment as a possible constraint on the discriminatory exercise of peremptory challenges. See, e.g., Marder, supra note 79, at 1132-34 (proposing elimination of all peremptory challenges in order to vindicate Sixth Amendment's requirement of "impartial" jury); Toni M. Massaro, Peremptories or Peers?-Rethinking Sixth Amendment Doctrine, Images, and Procedures, 64 N.C. L. REV. 501, 541-63 (1986) (proposing elimination of prosecutor's peremptory challenges to produce jury that satisfies Sixth Amendment's impartiality, community representation, and peer representation 
guarantee. ${ }^{249}$ Yet this solution faces a significant obstacle: the Supreme Court's 1990 opinion in Holland v. Illinois. ${ }^{250}$ There a bare majority of the Court rejected the notion that discriminatory peremptory challenges might harm the reliability of verdicts; the Court maintained that such challenges enhance rather than detract from reliability by allowing the litigants to remove potentially biased jurors from the panel. ${ }^{251}$ But two crucial inconsistencies weaken the Holland majority opinion. First, three of the five Justices in the Holland majority have embraced the theory of difference in their opinions in the Batson line of cases. ${ }^{252}$ That embrace should lead these Justices to see that a reliable verdict is, at least in part, a verdict pronounced by a jury that

requirements); Wendy Lynn Trugman. The Representatwe Jun Standard. An Altemattve to Batson $v$ Kentucky, 23 AM. CRIM. L. REV. 403 (1986) (criticizing intent-based equal protection theory of Batson. and proposing effects-based theory based on Sixth Amendment's representauve cross-section requirement)

249. Nancy King proposes a different solution in her comprehensive article See supra note 79 Canvassing the social science literature on the decisionmaking effects of racial prejudice. King concludes that it is possible for reviewing courts actually to measure the effects of discnmination in al least sorne cases. She seems to argue that reversal should be confined to those cases where social seience data strongly predict that discrimination played a role in the verdict. In a sense. King disputes the Court's instinct that Batson error is structural; she believes that it is like trial error, in that its precise impact on the verdict can be measured. See Arizona v. Fulminante, 499 U.S. 279. 310-11 (1991) (Rehnquist. C J. for Court in pan and dissenting in part) (explaining difference between trial and structural error).

I have one major objection to King's solution, and the Coun would surely have another Mly hesitation is that the social science data do not actually permit the sort of fine-tuned measurement that King would expect of them. King concedes as much. In summarizing the measunng value of the data she has catalogued, she allows no more than this:

[T] he studies would support a finding of a high probability of prejudice from jury discrimination if a black defendant could establish that he was convicted and sentenced to death for killing a white police officer by an all-white jury that heard racial eptthets dunng tnal and deliberations. when the case turned on the defendant's claim of self-defense and evidence of guilt was close-primarily a swearing match between black defense witnesses and the offieer's partner-and when legal selection procedures would probably have produced a jury w th at least three blacks. Conversely, the studies suggest a low probability that a white defendant indicted for sexually abusing a black child would be prejudiced by disenminatory selection practices that reduced the number of blacks on the grand jury by one.

King, supra note 79 , at $100 \mathrm{n} .138$. But these cases are far 100 easy to be llluminaung. We do not need to rely on social science for these results; our own common sense instıncts do just fine King's solutıon is therefore not really a solution, because the rule would not help courts decide hard cases

The Court would undoubtedly have an even more basic objection to King's solution King hinges her entire claim that the effects of race prejudice are measurable on social science data. This is. of course. her only choice, as jury deliberations are secret, and testimony about those deliberations generally inadmissible See FED. R. EVID. 606(b). But the Court has grown extremely hostule to the notion of building rules. especially equal protection rules, on social science data. See McCleskey v. Kemp. 481 U S. 279 (1987) (refusing to rely on extensive empirical study of capital punishment in Georgia): see also Ballew v. Georgia, 435 U.S. 223, 246 (1978) (Powell, J., concurring in the judgment) (questıoning Justıce Blackmun's "heavy reliance on numerology derived from statistical studies" to establish that five-member junes violate Sixth Amendment); Craig v. Boren, 429 U.S. 190. 204 (1976) ("It is unrealistıc to expect etther members of the judiciary or state officials to be well versed in the ngors of expernmental or stalistical technique But this merely illustrates that proving broad sociological proposituons by stalisues is a dubrous business. and one that inevitably is in tension with the normative philosophy that underlies the Equal Protection Clause ") King offers no reason why the Court would be more inclined to base a rule on social science dala in this area than in any other.

250. 493 U.S. 474 (1990).

251. See id. at 484 .

252. These are Chief Justice Rehnquist and Justices O'Connor and Scalıa. See infra text accompanying notes $285-86$. 
represents distinctive groups in the community. Second, the Holland majority's position is inconsistent with the Sixth Amendment's Jury Clause, which demands a jury that strikes an acceptable balance between the sometimes conflicting demands of impartiality and community representation. I now turn to these two important inconsistencies.

\section{A. The Theory of Difference and the Subversion of the Scientistic Verdict}

Two lines of Supreme Court cases are the focus of this Article: one expanding the Batson norm and the other expanding harmless error doctrine. In these two lines of cases, two discrete camps of Justices have been working at cross-purposes. The Justices who have pushed the hardest to prioritize verdict reliability as the preeminent value in the criminal process have also been the loudest opponents of the Batson norm; ${ }^{253}$ and the proponents of the Batson norm have been the Justices who have resisted the Court's sole focus on verdict reliability. ${ }^{254}$

I have already noted how neither camp has been able to devise an internally consistent account of the fair trial harm that Batson error causes. Yet

253. This camp of Justices currently consists of Chief Justice Rehnquist and Justices Scalia and Thomas. Of this group, only Chief Justice Rehnquist was on the Court when Batson was decided. However, Justices Scalia and Thomas have repeatedly expressed the view that Batson was a mistake. See Georgia v. McCollum, 505 U.S. 42, 69-70 (1992) (Scalia, J., dissenting) (objecting to gradual destruction of defendants' rights to peremptory challenges); $i d$. at 60 (Thomas, J., concurring in judgment) ("I write separately to express my general dissatisfaction with our continuing attempts to use the Constitution to regulate peremptory challenges."); Powers v. Ohio, 499 U.S. 400, 431 (1991) (Scalia, J., dissenting) ("Even if I agreed that the exercise of peremptory strikes constitutes unlawful discrimination (which I do not) . . . "); see also J.E.B. v. Alabama ex rel. T.B., 114 S. Ct. 1419, 1439 (1994) (Scalia, J., dissenting) (arguing against extension of Batson to sex).

Chief Justice Rehnquist wrote the opinion in Fulminante that expanded harmless error doctrine 10 coerced confessions, and was joined by (among others) Justice Scalia. See Fulminante, 499 U.S. at 281. Justice Thomas was not on the Court at the time of Fulminante, and he has not yet had the opportunity to indicate that he shares the Court's focus on verdict reliability as the central value in the criminal process. As Justice Thomas seems to share Justice Scalia's and Chief Justice Rehnquist's voting pattcrns, particularly in criminal cases, it seems fair to assume that he shares this particular viewpoint as well. See Christopher E. Smith, The Constitution and Criminal Punishment: The Emerging Visions of Justices Scalia and Thomas, 43 DRAKE L. REV. 593 (1995); Richard G. Wilkins et al., Supreme Court Voting Behuvior: 1994 Term, 22 HASTINGS CONST. L.Q. 269, 289 (1995) (noting comparable voting patterns among Rehnquist, Scalia, and Thomas in criminal cases); The Supreme Court, 1994 Term, 109 HARV. L. REv. 10. 341 (1995) (showing that in $1994 \mathrm{Term}$, Thomas voted with Scalia $88.2 \%$ of time and with Rehnquist 81.4\% of time); The Supreme Court, 1993 Term, 108 HARv. L. REV. 26, 373 (showing that in 1993 Term, Thomas voted with Scalia $82.8 \%$ of time and with Rehnquist $67.8 \%$ of time); The Supreme Court. 1992 Term, 107 HARV. L. REV. 27, 373 (1993) (showing that in 1992 Term, Thomas voted with Scalin $86 \%$ of time and with Rehnquist $82.5 \%$ of time); The Supreme Court, 199/ Term, 106 HARV. L. REv. 19, 379 (1992) (showing that in $1991 \mathrm{Term}$, Thomas voted with Scalia $85.9 \%$ of time and with Rehnquist $80 \%$ of time).

254. There is nearly a one-to-one correspondence between majority votes in Batson and dissenting votes in Fulminante. The Batson majority included Justices White, Marshall, Blackmun, and Stevens (in addition to Justices Brennan and Powell); these four were the four dissenters in Fulminante on the question of whether harmless error analysis should apply to coerced confessions. Notably, their position in Fulminante was not just that coerced confessions impugn the reliability of verdicts, but also that coerced confessions should trigger automatic reversal because they offend other important values. See Fulminumte, 499 U.S. at 293 (White, J., for Court in part and dissenting in part). 
there is a more fundamental inconsistency in the position of the Batson opponents, an inconsistency with grave ramifications for the enterprise of protecting the reliability of criminal verdicts.

The problem for the Batson opponents begins with their ready embrace of the theory of difference. By asserting that it is rational for an attorney to attribute a particular viewpoint to a prospective juror on account of his or her race or gender and to strike the juror on the basis of that rational inference, the Batson opponents commit themselves to a very basic-and, indeed, somewhat radical-proposition about the nature of the criminal verdict. This proposition is that verdicts are influenced and even determined not just by the evidence in the case, but also by the racial and gender composition of the jury itself. If it is rational for an attorney to infer that, say, a Latino juror will bring certain views into the jury room, and to try to remove that juror on the strength of that inference, it must also be rational to conclude that that juror's views could help determine the verdict. What is this but to admit that two lawfully constituted juries $^{255}$ of differing racial and gender composition could view the same evidence yet reach different conclusions ${ }^{256}$ on the ultimate question of guilt or innocence? $?^{257}$ Is this not what the verdicts in the two so-called "Rodney King" cases suggested? In these two prosecutions, two different lawfully composed juries reviewed similar evidence on similar charges and reached different verdicts. This is certainly not an airtight demonstration that race and gender shape criminal verdicts; the charges and evidence in the prosecutions were not identical, and, perhaps more importantly, the riots that took place between the two trials may have influenced jurors. Still, there was virtual consensus that the ethnicity of the two juries helped shape their verdicts. ${ }^{23}$

255. By two "lawfully constituted juries." I mean two junes from which all jurors subject to challenge for cause have been removed.

256. Reviewing social science research, Mark Cammack recently concluded that "Two consescntious jurors exposed to the same evidence may develop reconstructions of the facts and implications of those facts that are "surprisingly dissimilar."' Cammack, supra note 29, at $\$ 76$ (quotung Willtam C Thompson et al., Death Penalty Attitudes \& Conviction Proneness. 8 LAw \& HuM. Beriav. 95, 110-11 (1984)) As Cammack noted, this does not necessarily translate into different vendicts: "IDJiversifying the jury's standards for describing the social world may ennch the factfinding process generally without systematically orienting it toward conviction or acquittal." Id. al 479. Sull. Cammack agreed that "there is a demonstrated correlation between race and decision in at least some cases." /d. (citing Johnson. supra note 79, at 1625-43; King, supra note 79, at 80-91); see also Brown, supra note 27. at 117 (notung that race and gender influence jury voting). But see Jeffrey E. Pfeifer. Comment. Reviesing the Empurtcal Evidence on Jury Racism: Findings of Discrimination or Discrummaton Findings'. 69 NEs L REY 230. 241-50 (1990) (questioning validity of social science research in this area).

257. It is no response to say, as Batson's opponents do. that the value of the unfettered peremptory is that it allows the paries to work against precisely this outcome by cleansing the jury of bias and thereby enhancing impartiality. Not only is such a goal unattanable in practice, as the law now here allocates to a party an unlimited number of peremptory challenges, but it is also undesirable in theory The Sixth Amendment does not command singleminded pursult of an impartual jury. "t requires a balance of. of compromise between, the sometimes conficting norms of impartiality and community representation See infra text accompanying notes 302-05.

258. See generally Colloquy, Racism in the Wake of the Los Angeles Riots, 70 DENV U' L REV 187 (1993) (addressing systematic nature of racism in wake of Los Angeles unrest). Sy mposium. Los Angeles. April 29, 1992 and Beyond: The Law; Issues, and Perspecmes, 66 S CAL L ReY 1313 (1993) 
This, then, is the consequence of the Batson opponents' embrace of the theory of difference: a corresponding embrace of the view that verdicts are, at least in part, socially rather than scientifically determined. ${ }^{259}$ I have characterized this as a "somewhat radical" view of the criminal verdict because it diverges so sharply from the conception of the criminal verdict that the Batson opponents express in the harmless error cases. ${ }^{260}$ In those cases, the jury is a factfinder applying mechanical tests to discrete bits of empirical evidence, and the verdict is the certifiably reliable statement of historical truth that results from that testing. In their Batson opinions, however, the Batson opponents effectively concede that verdicts are not just findings of empirical, historical fact, but are at least in part the products of racially, sexually, or otherwise experientially influenced perspectives. ${ }^{261}$

The recognition that criminal verdicts are experientially constructed judgments rather than findings of immutable historical fact could lead to two possible conclusions about harmless error doctrine. One of these-the more extreme of the two-is that the entire institution of harmless error review is built on a lie. The harmless error enterprise is, after all, designed to protect the reliability of the criminal verdict. If verdicts are simply incapable of being "reliable" in any ordinary sense of that term, because they are the products of life experience, subjective viewpoint, and value judgment, then the idea of reserving appellate reversal for errors that threaten the value of reliability is rather dishonest. ${ }^{262}$

However, it does not follow from the Batson opponents' embrace of the theory of difference that juries engage in nothing that we would recognize as "fact-finding," or that verdicts are solely the product of subjective judgment.

(addressing legal, political, and cultural circumstances that precipitated unrest in Los Angeles following first Rodney King verdict).

259. Here Batson's opponents reject the empiricism of Batson's proponents and reveal strong contextualist leanings. See supra notes 66-75 and accompanying text.

260. The view does not strike me as particularly radical in the abstract. Admittedly, it would be radical if juries were required to reply to special interrogatories on discrete factual questions in criminal cases, rather than to announce a general verdict on the overall question of guilt or innocence. If this were our system's practice, jury verdicts would look a lot more like the findings of historical fact that the Court seems to imagine in its harmless error cases. But as a rule, juries in this country issue general verdicts on the question of guilt or innocence. This is a more ambiguous determination-one which does not fit as comfortably into a model of historical fact. For a discussion of the prevailing preference for general verdicts in criminal cases, see Albert W. Alschuler \& Andrew G. Deiss, A Brief History of Criminal Jury in the United States, 61 U. CHI. L. REV. 867, 912-13 (1994); Scott W. Howe, Jury Fact-Finding in Criminal Cases: Constitutional Limits on Factual Disagreements Among Convicting Jurors, 58 Mo. L. REV. I, 49 n.179 (1993); Anne Bowen Poulin, The Jury: The Criminal Justice System's Different Voice, 62 U. CIN. L. REv. 1377, 1398, 1420-23 (1994); Eric S. Miller, Note, Compound-Complex Criminal Statutes and the Constitution: Demanding Unanimity as to Predicate Acts, 104 YALE L.J. 2277, 2304 (1995).

261. Stated a bit differently, it cannot simultaneously be true that a jury's sole function is reliably to uncover a preexisting empirical fact, and that the racially or sexually influenced perspectives that jurors bring to the jury room actually have an impact on the verdict. Yet this is exactly what the opinions of the Batson opponents say, when read together with their opinions in the harmless error cases.

262. For a similar view in the far broader context of epistemology (rather than the narrow context of harmless error review), see Cammack, supra note 29, at 420 . 
Simple common sense tells us that some kinds of errors are more likely than others to mislead or inflame all juries, regardless of their composition. The insight of the Batson dissenters into the nature of the criminal verdict does not require the complete abandonment of the harmless error enterprise, ${ }^{263}$ merely an adjustment to it. For even though this insight does not subvert the entire structure of harmless error doctrine, it does show that the scientistic model of "reliability" on which the doctrine currently rests is stunted. In a world where it is rational to attribute distinctive perspectives to discrete groups within the community, a "reliable" verdict is not a verdict pronounced by a jury that has seen the strength of those perspectives diminished through peremptory challenges. ${ }^{264}$ Such a verdict will not reliably reflect the consensus of the community, and the entire community will not accept such a verdict as a reliable judgment. ${ }^{265}$ This, then, is the second, more sensible conclusion that should flow from the Batson opponents' commitment to the theory of difference: a reliable verdict becomes the consensus of a jury whose membership incorporates those distinctive perspectives. ${ }^{266}$

This is admittedly an incomplete definition of a reliable verdict. Representation is a necessary, but not sufficient, condition of reliability. To produce a "reliable" verdict, a trial must not only be judged by a jury that represents the discrete perspectives of the community, but it must also be free of the traditional reliability-impairing errors that the Court has identified in its harmless error cases. The important point here is that the reliability of a verdict is inseparable from the representativeness of the jury. The image of the jury as a scientific laboratory is fatally incomplete; in order to fulfill its central mission of producing reliable verdicts, a criminal jury must incorporate and represent the distinctive views of the community.

\section{B. The Representative Jury: Batson's Opponents Take a Wrong Turn in Holland}

Unlike the first of the two possible conclusions from the Batson opponents' endorsement of the theory of difference, the conclusion that reliability depends, in part, on community representation is not radical at all. The Supreme Court has Iong recognized that the "jury" guaranteed by the Sixth Amendment must be constituted in a way that allows it to speak with the voice of the community. In its cases on jury size, for example, the Court has held that a jurisdiction may shrink its juries from the traditional twelve to as few as six members because this reduction does not excessively imperil the

263. Again, Mark Cammack has made a simslar point in the broader context of theories of knowledge See id. at 421.

264. See infra text accompanying notes 302-05

265. See supra note 85.

266. See infra text accompanying notes 302-05; see also Marder, supra note 79. at 1066-74 
"possibility for obtaining a representative cross-section of the community."267 Five-member juries, however, are not the "juries" guaranteed by the Sixth Amendment, because the drop below six "prevents juries from truly representing their communities."268 The Court has said the same thing in its cases on jury unanimity. It has approved verdicts reached by ten out of twelve jurors ${ }^{269}$ because such verdicts do not excessively endanger any crucial value in the Sixth Amendment, including representation of the community. ${ }^{270}$ But it has condemned verdicts reached by five out of six as too grave a threat to those values. ${ }^{271}$ Thus the notion that the "jury" defined by the Sixth Amendment must be a body that represents the community is hardly novel.

Yet this is precisely where the opponents of Batson tumble into their deepest inconsistency. In 1990, the case of Holland v. Illinois ${ }^{272}$ presented these Justices with the opportunity to make good on the commitment to the theory of difference that they had shown, and would continue to show, in their opinions in the Batson line of cases. The defendant argued in Holland that a jury selected through the racially discriminatory use of peremptory challenges was not the "jury" guaranteed by the Sixth Amendment. ${ }^{273}$ In effect, the defendant asked the Court to find that race discrimination in the selection of petit juries violated not just equal protection values, as Batson had established, but a Sixth Amendment value as well. The claimed Sixth Amendment value

267. Williams v. Florida, 399 U.S. 78, 100 (1970).

268. Ballew v. Georgia, 435 U.S. 223, 239 (1978) (Blackmun, J.). There is some confusion as to whether Justice Blackmun's opinion in Ballew is for the Court, or whether only Justice Stevens joincd it. While not a foolproof summary of the opinion, the Syllabus prepared by the Reporter's Office suggests that only Justice Stevens joined Justice Blackmun's opinion. See id. at 223 . This is technically true: Only Justice Stevens agreed with Justice Blackmun's views both that the five-person jury violated the Sixth and Fourteenth Amendments and that the appropriate remedy was a new trial. Yet in a separate one-paragraph opinion, joined by Justices Stewart and Marshall, Justice Brennan stated that he "join[ed] Mr. Justice Blackmun's opinion insofar as it holds that the Sixth and Fourteenth Amendments require juries in criminal trials to contain more than five persons." Id. at 246 (Brennan, J.) (emphasis added). This group of three Justices did not think a new trial was the appropriate remedy for unrelated reasons, but quite clearly did join Justice Blackmun's opinion-not just the judgment-on the Sixth Amendment issue. Contrary to the suggestion in the syllabus of the decision, it seems that Justice Blackmun's Sixth Amendment analysis did attract five votes. In addition, Justice White explicitly agreed that a five-person jury violated the Sixth Amendment because "a jury of fewer than six persons would fail to represent the sense of the community ...."Id. at 245 (White, J., concurring in judgment).

269. See, e.g., Apodaca v. Oregon, 406 U.S. 404 (1972) (plurality opinion). The Court also upheld a verdict reached by nine out of twelve jurors against a due process and equal protection challenge in Johnson v. Louisiana, 406 U.S. 356, 362-65 (1972).

270. See Apodaca, 406 U.S. at $410-11$.

271. See Burch v. Louisiana, 441 U.S. 130, 134-39 (1979). The Court in Burch was very clear that the five-sixths voting rule was unconstitutional under the Sixth and Fourteenth Amendments because it "sufficiently threaten[ed] the constitutional principles that led to the establishment of the size threshold" of six that the Court had established in Ballew. Id. at 139. Those principles, of course, included the principle that a jury must represent the community. See supra note 268 and accompanying text.

272. 493 U.S. 474 (1990).

273. See id. at $477-78$. The defendant, a white man objecting to the exclusion of black jurors, also had to argue that he had standing to raise the Sixth Amendment claim. The Court agreed that he did. See id. at 476-77. 
was, of course, exactly the one that the Cour had identified in its jury size and jury unanimity cases-jury representativeness. ${ }^{274}$

Voting five to four, the Court-in an opinion written by Justice Scalia, perhaps the most vocal of Batson's opponents-rejected the defendant's claim. ${ }^{275}$ The Court gave two reasons for its decision, one doctrinal and the other practical. First, the Court interpreted its cases to establish the proposition that "representativeness" is constitutionally required only of the venire from which petit juries are chosen. ${ }^{276}$ There is no constitutional value of representation at the level of the petit jury actually seated, the Court reasoned; a state might have (and act upon) any legitimate reason for "disrupt[ing]" the representativeness of the venire in seating its juries. ${ }^{27}$ Second, the Court held that any other conclusion was impractical and, therefore, unthinkable. Repeating its oft-stated views that "'[d]efendants are not entitled to a jury of any particular composition"'278 and that petit juries need not precisely " "reflect the composition of the community at large," "'279 the Court saw no stopping point to the defendant's argument. ${ }^{280}$ If the Sixth Amendment required representativeness at the stage of the petit jury (as opposed to the venire), then "intentionally using peremptory challenges to exclude any identifiable group should be impermissible." 281 Such a rule, the Court worried, would either make it impossible ever to seat a jury in any case, or, what was more likely, destroy the ancient institution of the peremptory challenge. ${ }^{282}$

The Court's decision in Holland is hard to fathom. At a purely doctrinal level, the Court's holding that the Sixth Amendment has nothing to say about the representativeness of seated juries is rank revisionism of earlier Sixth Amendment cases. One need look no further than the cases on jury size and jury unanimity ${ }^{283}$ to see that community representation is a Sixth Amendment value at the level of the seated petit jury. What separated the six-member jury in Williams from the five-member jury in Ballew, and the ten-out-of-twelve

274. See id. at 478.

275. See id. at 477-88. Joining Justice Scalia in the Holland majonty were Chief Justuce Rehnquist and Justices White, $O^{\prime}$ Connor, and Kennedy. Justices Brennan, Marshall, Blackmun. and Stevens dissented. All of the Holland dissenters were in the Batson majoniy, as were Jusuces White and O'Connor Sec Batson v. Kentucky, 476 U.S. 79.81 (1986).

276. See Holland, 493 U.S. at 482-83 (citing Lockhart v McCrec. 476 U S 162, 173-75 (1986))

277. See id. at 483. The legitimate state interest that the Coun saw in Holland for skewing the representative nature of the jury was "the assurance of impartiality that the system of peremptory challenges has traditionally provided." Id. But see infra text accompanying notes 302-05

278. Holland, 493 U.S. at 483 (quoting Taylor v. Loussiana. 419 U S 522. 538 (1975))

279. Id. (quoting Lockhan v. McCree, 476 U.S. 162, 173 (1986))

280. See id. at 484-86: see also id. at 488 (Kennedy. J.. concurnng) (arguing defendant's contention "admits of no limiting principle to make it workable in practuce")

281. Id. at 484.

282. See J.E.B. v. Alabama ex rel. T.B., 114 S. C1. 1419. 1439 (1994) (Scalia. J. dissentung) (describing peremptory challenge as "a practice that has been considered an essentual pant of faur jury tral since the dawn of the common law").

283. See supra notes $267-71$. 
voting rule in Apodaca from the five-out-of-six rule in Burch, was the Sixth Amendment value of community representation: The Williams and Apodaca regimes satisfied it; the Ballew and Burch regimes did not. Georgia surely had minimally "legitimate" reasons to seat juries of five, and Louisiana to accept verdicts from five-if none other than speed, convenience, and expense. Yet the Court never suggested that the Sixth Amendment value of community representation could be overcome by such reasons. The Holland Court's refusal to recognize that the Sixth Amendment's protection of jury representation extends beyond the venire to the petit jury itself is untrue to the Court's own Sixth Amendment cases. ${ }^{284}$

Moreover, by refusing to acknowledge a Sixth Amendment value of community representation at the level of the petit jury, three of the five Justices in the Holland majority are untrue to their own embrace of the theory of difference in their opinions in the Batson line of cases. ${ }^{285} \mathrm{By}$ virtue of that embrace, these three Justices, Chief Justice Rehnquist and Justices Scalia and O'Connor, commit themselves to the idea that in the context of jury deliberations, race and gender "matter[]"286 - to the deliberations, to the outcomes of those deliberations, and to public acceptance of those outcomes. As explained above, this analytic move should commit these Justices to a particular vision of the criminal verdict, and indeed, of the criminal jury itself-a vision that insists on full representation of the community as a condition of reliable verdicts. ${ }^{287}$ Yet exactly this broad vision is lacking in Holland. There, these same Justices tell us that the Sixth Amendment is not even concerned with representation. This very deep and basic contradiction suggests that these Justices simply failed to face the consequences of their views. To be true to Sixth Amendment precedent, and to their own insights

284. In his opinion for the Court in Holland, Justice Scalia seemed at times to pretend that the jury size and jury unanimity cases never happened. For example, Justice Scalia asserted that "[t]he Sixth Amendment requirement of a fair cross section on the venire is a means of assuring, not a representative jury (which the Constitution does not demand), but an impartial one (which it does)." Holland v. Illinois, 493 U.S. 474, 480 (1990). If the Sixth Amendment does not assure a representative jury, then what could possibly support the Court's holdings in Williams, Ballew, Apodaca, and Burch? What would stand in the way of a jury of five? Or less than five? Or a verdict by simple majority of a three-person jury?

At other times, Justice Scalia acknowledged that these precedents were on the books, but read them as isolated decisions devoid of any meaning beyond their facts. "While statements in our prior cases have alluded to ... a "fair possibility" requirement," he wrote, "satisfying it has not been held to require anything beyond the inclusion of all cognizable groups in the venire, see Lockhart v. McCree, 476 U.S. 162 (1986); Duren [v. Missouri, 439 U.S. 357 (1979)]; Taylor [v. Louisiana, 419 U.S. 522 (1975)], and the use of a jury numbering at least six persons, see Ballew v. Georgia, 435 U.S. 223 (1978); Williams v: Florida, 399 U.S. 78 (1970)." Holland, 493 U.S. at 478. This is not reasoning; this is list making. What Justice Scalia omitted, besides the jury unanimity cases, was the reason that the Sixth Amendment condemns five-person juries or nonunanimous verdicts from six-person juries, the underlying idea that links Lockhart, Duren, and Taylor with Ballew and Williams (and, for that matter, Apodaca and Burch as well). That underlying constitutional idea is the Sixth Amendment's insistence that a jury represent the community from which it is drawn.

285. See supra notes $66-75$ and accompanying text.

286. J.E.B., 114 S. Ct. at 1432 (O'Connor, J., concurring).

287. See supra Section VI.A. 
about the nature of the criminal verdict and the criminal jury, the Holland majority should have acknowledged that community representation is a constitutional requirement, even at the level of the seated petit jury. ${ }^{.85}$

Of course, to read Justice Scalia's opinion in Holland, the Justices in the majority had the best of reasons to rule as they did. The Court has long, and wisely, resisted any suggestion that juries must be exact mirrors of the communities from which they are drawn. ${ }^{289}$ Even in the most strictly homogeneous of places, a single jury cannot possibly replicate the exact racial, ethnic, and gender mix of the community from which it is drawn, let alone the mix of religions, professions, hobbies, and other interests that might break the community into "identifiable groups." The hope that all juries might do so is just that-a vain and impractical hope. This vain hope is what the Holland majority imagined to be the logical conclusion of the defendant's Sixth Amendment argument. ${ }^{290}$ Thus the Justices in the Holland majority were undoubtedly right to fear the result that they imagined.

Yet they were wrong to imagine only the result that they feared. ${ }^{291}$ The defendant in Holland was not asking the Courn to require mirror-image representation. The defendant simply was asking the Court to apply the Batson rule. ${ }^{292}$ This is an important difference: It is the difference between an

288. Akhil Reed Amar has argued powerfully that the enmınal juny was designed as a representature democratic body-in his words, "a political institution embodying popular sovereignty and republican selfgovernment." Amar, supra note 85, at 684. Junes, according to Amar, are "supposed to represent the polity-the people," even if such representation might "trump a given defendani's desires" I $d$ at 685

Amar praises the Court for adopting and extending the Batson norm; he sees the Barson line of cases as implementing the Constitution's commitment to a representauve jury. Sec id at 685 I agree with Amar that the results of the Batson line of cases help achieve a more representatuve jury Yel 1 am puzzled by Amar's assertion that the Court here "has been on just the nght track: Id If the notion that a cnminal jury must represent the community is, as the title of his article implies, a "Sixth Amendment first pronciple." then the Court ought not be praised for sneaking a Sixth Amendment first pnnesple into the Equal Protection Clause of the Fourteenth Amendment. It should instead be cnictzed for faling. as it did in Holland, to enforce a Sixth Amendment first pnnciple under the Sixth Amendment

289. See Lockhart v. McCree, 476 U.S. 162. 173-74 (1986): Duren v Mlsssoun, 439 U S 357. 364 n.20 (1979); Taylor v. Louisiana, 419 U.S. 522. 538 (1975).

290. See Holland v. Illinois, 493 U.S. $474,484-85$ (1990)

291. Other models for the claimed Sixth Amendment nght were readily avalable to the Holland majority, especially two well-known state decisions that interpreted state constututional jury inal guarantees in much the way Holland proposed for the Sixth Amendment. See People v Wheeler, 583 P2d 748 (Cal 1978); Commonwealth v. Soares, 387 N.E.2d 499 (Mass. 1979) For a thorough diseussion of these cases. see William T. Pizzi, Batson v. Kentucky: Curing the Disease But KIllung the Pattent. 1987 SLP CT REV 97, 103-06.

292. Holland's attorney's strategic decision to litigate under the Sixth Amendment rather than the Equal Protection Clause might seem odd: If Batson already provided the necessary rule, why look for one in the Sixth Amendment as well? The simple answer is that the defendant in Hollorid was white. and the Supreme Coun had not yet decided Powers, which permitted defendants not of the sume race as excluded jurors to avail themselves of the Batson rule. See Powers v Oho. 499 U S 400 , $40-11991$ ) Holland's attorney most likely thought that he had a better chance of establishing standing under the Sixth Amendment than under the Equal Protection Clause. See The Supreme Courn. 1939 Term-Leadeng Cuses. 104 HARV. L. REV. 129, 169 n.10 (1990).

As things turned out, this was a bad strategy. Shorly after Holland lost his Sixth Amendment argument, another white defendant persuaded the Court to adopt the equal protection analysts that Holland's attomey had avoided. See Powers, 499 U.S. at 404 (1991) But II was an enomousl) iellıng strategy. 
affirmative and a negative formulation of the Sixth Amendment's requirement of community representation. In its earlier cases on the representation requirement, the Court defined the requirement negatively: To seat juries that are sufficiently representative of the community to satisfy the Sixth Amendment, a jurisdiction may use twelve jurors, or it may use six, or it may (presumably) use sixty. But it may not use fewer than six. ${ }^{293}$ Thus, representation does not affirmatively require any particular number of jurors above six, but it does forbid juries of fewer than six.

The Holland Court pretended that the only way to implement the Sixth Amendment's requirement of community representation was with an affirmative rule: To be representative, a jury must look exactly like the community. However, the Court could just as easily implement the norm of representation with a negative rule: A jury is sufficiently representative of the community to satisfy the Sixth Amendment when it is chosen from a representative venire without a violation of the Batson rule. ${ }^{294}$ It is all a

revealing the gaping fair trial hole at the center of Batson. Holland's attorney faced a problem of standing: How could a white defendant have standing to lodge a Batson objection to the exclusion of black jurors? The law of standing would require Hoiland to show that he had suffered a "concrete injury" from the exclusion of black jurors. See Lujan v. Defenders of Wildlife, 504 U.S. 555,567 n.3 (1992). Holland's attorney undoubtedly read Batson and saw no way to articulate any real equal-protection-based harm that a white defendant could possibly suffer from the exclusion of black jurors. This was certainly not an unreasonable reading of Batson. See supra Part IV. The Sixth Amendment, with its insistence on community representation, undoubtedly seemed a far safer choice. It was-at least on the issue of standing. The Holland Court had little trouble in concluding that a white defendant had standing to contest the exclusion of black jurors under the Sixth Amendment. See Holland, 493 U.S. at 474. Holland's lawycr's sensible choice to litigate under the Sixth Amendment says much about the curious lack of a fair trial injury at the core of Batson.

293. See supra notes $267-68$ and accompanying text.

294. On direct appeal, a claim of Batson error can reach an appellate court in two main ways. Commonly, a defendant claims that the trial court wrongly determined that the prosecutor did not violate Batson in challenging a juror. Here, the defendant is asking the appellate court to conclude that the prosecutor removed a juror on account of race or gender and in fact had no race- or gender-neutral grounds to doubt the juror's impartiality.

Less commonly, a defendant argues that the trial court wrongly found that defense counsel violated Batson in challenging a juror. Here, the defendant is asking the appellate court to conclude that defense counsel did in fact have race- or gender-neutral grounds to doubt the juror's impartiality, but that the trial court wrongly saw the peremptory as race- or gender-based. Only in the first of these two scenarios should the court find a structural Sixth Amendment error of the kind that I have described in this Article. This might seem odd at first. Both of these situations arguably present claims of Batson error, yet I am suggesting that only the former presents a Sixth Amendment structural error warranting automatic reversal. This is so because the latter claim is really not a claim of Batson error at all; it is simply a claim that the trial court wrongly stripped the defense of a statutorily conferred peremptory challenge.

A recent Ninth Circuit case shows why this is true. United States v. Annigoni, 57 F.3d 739 (9th Cir. 1995), concerned a bank fraud prosecution involving a real estate partnership. On voir dire, an Asian prospective juror named Jue Hom admitted that he had an investment in a real estate partnership and suggested that he knew of litigation over the investment. See id. at 741 . Defense counsel exercised a peremptory challenge against Hom. See $i d$. In response to the prosecutor's Batson objection, defense counsel explained that he was challenging Hom because of his investment background, not his race. See id. at 742. The district court found that defense counsel's peremptory was race-based and left Hom on the jury. See id. The jury convicted Annigoni. See id. at 741 .

To prevail on appeal, the defendant needed to convince the appellate court that defense counscl had not violated Batson by challenging Hom but in fact had a convincing race-neutral explanation for doubting his impartiality and wanting him off the jury. The injury that the defendant claimed he suffered was not 
question of where the Court sets the threshold for representation. The Court in Holland set the threshold impractically high, and then condemned the rule as impractical. The Batson rule presented the Holland Court with a lower, and more workable, threshold, much like the one the Court adopted in its jury size and jury unanimity cases. ${ }^{295}$ The Court was wrong to reject this more practical negative definition of the Sixth Amendment's requirement of community representation. ${ }^{296}$

What frightened the Holland majority was, of course, not just the notion that the Sixth Amendment might require juries to be exact racial mirrors of the community. The majority was also convinced that juries would have to mirror the community in every way, that attorneys would be forbidden from striking "not [just] blacks, but postmen, or lawyers, or clergymen, or any number of other identifiable groups." 297 The Court here was pointing out a difference between the Equal Protection Clause and the Sixth Amendment: For all of its flaws as a fair trial guarantee, ${ }^{298}$ the Equal Protection Clause at least provides a coherent basis for limiting the Batson rule to discrimination against minorities and women. The Holland majority evidently saw no way to impose a similar limit on a Sixth Amendment rule.

Yet surely there are stopping points on the road to full and proportional representation of all "identifiable groups" such as "postmen, or lawyers, or

harm to the representativeness of the jury. but harm to the impariality of the jury $A$ white-collar case about real estate parnerships ended up being judged by a jury that included a possibly defrauded investor in real estate partnerships. At bottom, this was simply a clam that the distnet coun mistakenly disallowed the defendant a peremptory challenge that he should have had as a matter of statutory nght See 28 U S C $\S 1870$ (1994).

The question on an appeal such as this is not how to remedy a Butson volation. because to reach the question of remedy, the appellate cour must first find that there was no Batson volation and consequently no harm to the Sixth Amendment value of community representation. The question on this appeal is rather how the cour should remedy the improper denial of a pary's statutory nght to a peremptory challenge The Annigoni court held that automatic reversal was not the appropnate remedy and affirmed the conviction. Annigoni, 57 F.3d at 745. The Third and Fifth Circults have reached the oppostte conelusion. opting for a rule of per se reversal. See Kirk v. Raymark Indus., 61 F 3d 147.162 (3d Cir 1995). United States v. Broussard, 987 F.2d 215, 217 (5th Cir. 1993). While this question is beyond the scope of this Article, the Annigoni court's approach appears far more consistent with the Supreme Court's clear hosulity to rules of automatic reversal for errors that do not plannly undermine the reliability of the jury's verdict. See supra Pan III.

295. Indeed, this distinction between affimative and negative rules of representation is one that the Court has drawn in its jury discrimination cases. See, e.g.. Canter v Jury Comm n. 396 U S 320. 343 (1970) (Douglas, J., dissenting in part) ("We have often sad that no jury need represent propontonally a cross-section of the community ... . Jury selection is largely by chance: and no matter what the race of the defendant, he bears the risk that no racial component. presumably favorable to hum. will appear on the jury that tries him. The law only requires that the panel not be purposely unrepresentatuve "). Thicl v Southem Pac. Co., 328 U.S. 217, 220 (1946) ("[Amencan tradition of inal by jury] does not mean that every jury must contain representatives of all the economic. soctal, religious, ractal, political and geographical groups of the community... . But it does mean that prospeclive juron shall be selected by court officials without systematic and intentional exclusion of any of these groups ")

296. See Raymond J. Broderick. Why the Perempron Challenge Should Be Abolished. 65 TEMP L REV. 369, 408-10 (1992) (criticizing Holland for toleratıng systematic exclusion of identufiable communily groups through peremptory challenges).

297. Holland v. Illinois, 493 U.S. 474. 486 (1990).

298. See supra note 247. 
clergymen." $^{299}$ As explained above, ${ }^{300}$ the Sixth Amendment requires community representation on the petit jury not just for its educative or political value, ${ }^{301}$ but also because representation contributes crucially to the reliability of criminal verdicts. As most of the Justices in the Holland majority suggest in their opinions in the Batson line of cases, criminal verdicts are not just findings of historical fact, but expressions of an inescapably subjective consensus reached among jurors who bring discrete viewpoints and perspectives to their deliberations. Representation of these discrete viewpoints on the jury enhances the reliability of the criminal verdict, both by guaranteeing that the verdict will reflect a true social consensus, and by convincing the community as a whole that the verdict is worthy of respect.

The Holland majority avoided this insight by setting up jury impartiality as the only value of constitutional significance in the Sixth Amendment's Jury Clause: Justice Scalia was careful to distinguish between "a representative jury (which the Constitution does not demand)" and "an impartial one (which it does)." ${ }^{302}$ But this distinction is patently false. The Court's jury size and unanimity cases show that the "jury" described in the Sixth Amendment is not just an impartial body, but also a representative one. ${ }^{303}$ Community representation and impartiality may often be conflicting values, but they are both within the Sixth Amendment's command; the Court has the difficult job of striking a workable balance between the two values, not the easy job it assigned itself in Holland of abandoning one of them. Reliability, then, is not equal to impartiality, as the Holland Court would have it. Reliability sits at the intersection of impartiality and community representation.

It is from this insight about the criminal verdict, an insight that flows from the opinions of the Batson opponents themselves, that a limiting principle emerges. To be sure, postmen are, as Justice Scalia suggests, just as "identifiable" a group within the community as are blacks. Yet few communities are riven by discord about mail delivery. More importantly, no one has suggested that postmen are likely to hold unique views about the range of sensitive and potentially divisive issues that arise in criminal cases-views that people in other professions would likely not hold. The important question for the purpose of the Sixth Amendment inquiry is not whether a particular group is "identifiable," for surely there is an infinite number of such groups in any community. The important questions are whether a group is identifiable and whether an attorney might rationally deem its viewpoint genuinely

299. Holland, 493 U.S. at 486.

300. See supra Section VI.A.

301. On the educative and political functions of juries and jury service, see Akhil Reed Amar, The Bill of Rights as a Constitution, 100 YALE L.J. 1131, 1186-89 (1991); Amar, supra note 206; Amar, supra notc 47, at 217-21; Marder, supra note 79, at 1083-86, 1098-99; Underwood, supra note 43, at 749-50.

302. Holland, 493 U.S. at 480.

303. See supra note 284. 
distinctive; that is, whether the group likely has a perspective on the deeply divisive kinds of issues that can arise in criminal cases that another identifiable group is unlikely to share. ${ }^{304}$ It is the exclusion of that sort of identifiable group that undermines the Sixth Amendment's commitment to representation, ${ }^{305}$ and with it, the jury's mission of producing reliable verdicts.

This is not to say that groups defined by their race or their gender are the only groups whose purposeful exclusion from petit juries the Sixth Amendment would forbid. A limited number of other groups, such as religious groups,

304. See Cammack, supra note 29, at 480-81 ("[1]t cannot be dented that race. gender. and ethnicity are highly salient categories of social understanding in our sociely and have been for a very long ume ")

305. See Taylor v. Louisiana, 419 U.S. 522. 530 (1975) ("Restncung jury senice to onl) special groups or excluding identifiable segments playing major roles in the communtw cannot be squared ith the constitutional concept of jury trial." (emphasis added)). Of course, the jun serves more than one value Not only must it represent (or, more precisely, not designedly misrepresent) the communty, but it must also be "impartial." U.S. CONST. amend. VI. It is not difficult to see how the two values of community representation and impartiality might sometimes conflict with one another For example, some segment of the community undoubtedly deems the death penalty so unjust that its members would refuse even to consider voting to impose it in any case, regardless of the facts See Witherspoon v llinous. 391 I' S S10. 513 (1968). This segment of the community has come to be hnown as "Witherspoun excludables" in the case law. See Lockhart v. McCree, 476 U.S. 162, $167 \mathrm{n} .1$ (1986). To say that the Sixth Amendment forbids the purposeful underrepresentation of Wilherspoon excludables is to say that the Sixth Amendment requires the seating of "partial" jurors-jurors who cannot "lay aside [their] impression[s] or opinson[s] and sender a verdict based on the evidence presented in cour." In'in v. Dowd. 366 U S 717. 723 (1961). see. WfC Cree. 476 U.S. at 174 (rejecting claim that Witherspoon excludables are distunctue group withn community tor Sixth Amendment purposes).

Where these two values conflict, the Sixth Amendment should be read to require as reasonable an accommodation of them as possible. See Massaro, supra note 248. at $541-42$ (arguing that jun that satusties Sixth Amendment is one that meets requirements of impartialty. communty representation. and peer-group representation). It should not be read to require community representalion al all costs 1 . for example, a black juror stated on voir dire that he would be unable to set asside his belief that all police officers are evidence-fabricating liars utterly unworthy of belief, that juror would properly be excludable for cause. even if his views accurately reflected those of some segment of the blach community On the other hand. If an attomey challenged a black juror on the suspicion that that juror had had cenain life expenenees itat would cause him to doubt the veracity or integrity of police officers in some instances, the Sixth Amenumeni's concem for community representation would trump its concem for impanality. and the juror would sit See McCree, 476 U.S. at 176 (noting that jurors who "firmly believe that the death penaliy is unjust may nevertheless serve as jurors in capital cases so long as they state clearly that they are uslling to temporanly set aside their own beliefs in deference to the rule of law").

306. See Batson v. Kentucky, 476 U.S. 79, 124 (1986) (Burger, C.J, dissentung). Elaine A Carlson, Batson, J.E.B., and Beyond: The Paradoxical Quest for Reasoned Peremplon Sinkes in the Jun Selectuon Process, 46 BAYLOR L. REV. 947, 970-75 (1994) (analyzung propnety under Batson of relıgion-based peremptory challenges and of voir dire questions designed to probe prospective juror's religious beliefs). Brian E. Leach, Comment, Extending Batson v. Kentucky to Gender und Bevond The Deuth Kinell for the Peremptory Challenge?, 19 S. ILL. U. L. REV. 381,398 (1995) (summanzing case lau addressing possible extension of Batson to religion-based peremptones): Angela J Mlason. Note. Discrimintation Based on Religious Affiliation: Another Nail in the Perempton Challenge's Coffin?. 29 GA L REY $\$ 93$ (1995) (arguing that logic requires extension of Baison to religion. which will result in demise of peremptory challenge). But see J. Suzanne Bell Chambers. Note. Applving the Break Religion and the Perempton Challenge, 70 IND. L.J. 569 (1995) (arguing that extenston of Batson to peremplones exereised on atcount of religion is neither constitutionally required nor desirable as matter of policy)

To date, the courts have largely declined to extend Batson's protection to religious groups See State v. Davis, 504 N.W.2d 767 (Minn. 1993). cert. denied. 114 S Cl 2120 (1994). Casarez V Texus. 913 S.W.2d 468, 478 (Tex. Crim. App. 1995) (en banc) (holding. on reheanng. that peremptory challenges may be exercised on basis of religion in individual cases). Bus see Davis. $114 \mathrm{~S}$ Ct at 2120-22 (Thomas. J. dissenting from denial of certiorari) (arguing that logic of $J E B$ would require Coun to condemn 
might also qualify. The number of identifiable groups, however, would be relatively small, certainly not extending, as Justice Scalia worried in Holland, to "postmen, or lawyers, or clergymen"307 - or, to return to the example with which this Article began, to people who contribute to public broadcasting. In its cases on the Sixth Amendment's requirement of jury selection from a "representative cross-section" of the community, the Court has had little trouble limiting community representation to groups it deems "distinctive" within the community. ${ }^{308}$ The Court has quite sensibly rejected the claim that "groups defined solely in terms of shared attitudes that would prevent or substantially impair members of the group from performing one of their duties as jurors ... are ... 'distinctive groups' for fair-cross-section purposes." 309 Instead, the Court has deemed "distinctive" only those groups that play "major roles" in the community ${ }^{310}$ - groups such as blacks, women, and MexicanAmericans, ${ }^{311}$ who may share broad experiential influences on their perspective, yet who do not, as groups, predictably harbor the conscious and intractable biases that would render them invariably challengeable for cause. $^{312}$ The Court has plainly been able to manage the concept of community representation in its representative cross section cases. ${ }^{313}$ There

peremptory challenges exercised on religious grounds).

307. Holland v. Illinois, 493 U.S. 474, 486 (1990). See generally Laurie Magid, Challenges to Jury Composition: Purging the Sixth Amendment Analysis of Equal Protection Concepts, 24 SAN DIEGO L. REv. 1081, 1104-11 (1987) (describing judicial efforts to determine which community groups are cognizable for Sixth Amendment purposes). But cf. Marder, supra note 79, at 1104 (suggesting that "dividing peoplc according to distinctive groups is a difficult task and one that is likely to seem unfair to, and be divisive within, the community").

308. See Lockhart v. McCree, 476 U.S. 162, 174 (1986); Duren v. Missouri, 439 U.S. 357, 364 (1979).

309. $\mathrm{McCree}, 476$ U.S. at 174 (emphasis added).

310. Taylor v. Louisiana, 419 U.S. 522,530 (1975).

311. McCree, 476 U.S. at 175.

312. See supra note 29.

313. The lower federal courts have also proven themselves equal to this task. In Willis v. Zant, 720 F.2d 1212 (11th Cir. 1983), the court was presented with a claim that "young adults from age 18-30" were a distinctive community group for Sixth Amendment purposes. See id. at 1215 . To resolve this claim, the court laid down a test:

To show that a group is distinctive or cognizable under the sixth amendment, a defendant must show: (1) that the group is defined and limited by some factor (i.e., that the group has a definite composition such as by race or sex); (2) that a common thread or basic similarity in attitude, ideas, or experience runs through the group; and (3) that there is a community of interest among members of the group such that the group's interests cannot be adequately represented if the group is excluded from the jury selection process.

Id. at 1216 .

Other courts have applied the Willis test, or one like it, to reach the conclusion that young adults, and various other groups, do not constitute distinctive groups within the community for Sixth Amendment purposes. See United States v. Fletcher, 965 F.2d 781, 782-83 (9th Cir. 1992) (college students); Silagy v. Peters, 905 F.2d 986, 1009-11 (7th Cir. 1990) (people over 70); United States v. Canfield, 879 F.2d 446, 447 (8th Cir. 1989) (residents of Minneapolis); Ford v. Seabold, 841 F.2d 677. 681 (6th Cir. 1988) (young adults aged 18-29); United States v. Salamone, 800 F.2d 1216, 1218-20 (3d Cir. 1986) (members of National Rifle Association); Anaya v. Hansen, 781 F.2d 1, 5-8 (Ist Cir. 1986) ("blue collar workers" and "less educated individuals"); Barber v. Ponte, 772 F.2d 982, 997-1000 (1st Cir. 1985) (en banc) (young adults aged 18-34); United States v. Kleifgen, 557 F.2d 1293, 1296 (9th Cir. 1977) (unemployed, young, and non-high school graduates); United States v. Olson, 473 F.2d 686, 688 (8th Cir. 1973) (people aged 18-20). The Willis test is a sensible one. Coupled with the Supreme Court's admonition in McCree that 
is no reason to believe that the Court could not also do so in a case concerning the discriminatory use of peremptory challenges.

This proposal is, in a sense, a reworking of John Hart Ely's justly famous explanation of the ways in which racial and gender prejudice skew the legislative process. ${ }^{314}$ A premise of Ely's work is that identifiable groups in society have identifiable views and interests that often diverge from the views and interests of other groups. The democratic idea, however, is that these groups will ordinarily be able to negotiate and compromise with one another to work out mutually beneficial arrangements in the legislative process. Judicial review, according to Ely, should function to police failures of that democratic idea-situations where, because of prejudice, certain identifiable groups are perpetually unable to find common ground with enough others to secure legislative success. ${ }^{315}$

I am suggesting that certain groups may find it as difficult to find common ground with others in the jury room as they do in the legislature. Where there is purposeful exclusion of such groups, the result is a similarly deep, and similarly dangerous, flaw in representation. At bottom, the Sixth Amendment is concerned with preventing flaws in jury representation, much as the Fourteenth is with preventing the flaws of political representation that have been Ely's special concern. These amendments have at least one similar goal: Just as our legislatures must apportion benefits and burdens in a way that the entire community will respect and accept, our juries must do the same through their verdicts. Just as flaws in representation undermine the fairness of legislative outcomes, those flaws also undermine the reliability of criminal verdicts. ${ }^{316}$

distinctive groups do not include "any . . group defined solely in terms of shared altributes that render members of that group unable to serve as jurors in a particular casc." M/cCree. 476 U S at 176-77. the Willis test presents a workable way for courts to police the limuts of community representation

314. See John HaRT Ely, Democracy and Distrust 135-79 (1980)

315. See id.

316. Nothing that I have said in this Article demonstrates that the Sixth Amendment would suppon the result that the Court reached in Georgia v. McCollum. 505 U S 42. 48-55. 59 (1992). extending the Batson prohibition to criminal defense counsel. This does not mean that the Sixth Amendment delinitely would not support the result in McCollum: it means only that the question of whether the Sixth Amendment's Jury Clause protects the government as well as the accused is beyond the scope of this Anicle. On that subject, see generally Susan Bandes. Taking Some Rights Too Senoush The State's Right to a Fair Trial, 60 S. CAL. L. REv. 1019 (1987), as well as Amar. supra note 85. al 681-82

It is worth noting, however, that even if the Sixth Amendment forbade defense counsel from engaging in discriminatory jury selection, the question of the appropnate appellate remedy for such disenmunation would not arise. The Fifth Amendment's Double Jeopardy Clause would preclude the government from appealing any acquittal that followed from defense counsel's jury discrimination. and the govemment would have no incentive to complain if it obtained a conviction. The $\mathrm{McC}$ ollum case itself made its way to the Supreme Court only because the State had filed a pre-tnal motion to forbid defense counsel from siolating Batson, the trial cour had denied that motion. and the State was given permission to take an interlocutory appeal. See McCollum, 505 U.S. at 45.

In a similar vein, nothing in this Artele suggests that the Sesemth Amendment's jury tnal guarantee in civil cases would support the result that the Cour reached in Edmonson v: Leesville Contcrete Co. 500 U.S. 614 (1991). As noted earlier, the problem of discriminatory peremplory challenges in the civil seltung 
The potential link between popular representation in the legislature and on the jury is not lost on at least some members of the Court. In a very recent (and typically thoughtful) dissenting opinion in a voting rights case, Justice Souter noted that his view that states might permissibly use race in the drawing of voting district lines was at odds with Batson and the Court's other cases on the use of race in the exercise of peremptory challenges. ${ }^{317}$ Justice Souter asserted that legislatures and juries are distinguishable: "Politics," he wrote, "includes choices between different sets of social values, choices that may ultimately turn on the ability of a particular group to enforce its demands through the ballot box."318 "Jury decisionmaking," on the other hand, "is defined as a neutral process, the impartial application of law to a set of objectively discovered facts." $319 \mathrm{He}$ concluded that "[t]o require racial balance in jury selection would risk redefining the jury's role. ${ }^{\text {"320 }}$

While I do not argue in this Article for any sort of numerical "racial balance" in the selection of juries, I disagree with the rigidity in Justice Souter's distinction of legislatures from juries. If, as Justice Souter himself concedes, "race, especially as an imperfect proxy for experience, makes a difference in jury decisionmaking (and, in some cases, legitimately so),"321 then it cannot also be true that juries do nothing more than "impartial[ly] appl[y] law to a set of objectively discovered facts." ${ }^{322}$ Rather, juries, like legislatures, are a meeting place for the various experiences and, in Justice Souter's words, "sets of social values," of distinctive groups in the community. ${ }^{323}$ To recognize this is not to redefine the jury's role; it is to give life to the very same aspect of the jury's role that animated the Court's cases on jury size and unanimity: the jury as a representative of the community from which it is drawn.

is beyond this Article's scope. See supra note 18. On the issue of community representation on the civil jury, see generally Phoebe A. Haddon, Rethinking the Jury, 3 WM. \& MARY BILL. RTS. J. 29 (1994).

It bears mentioning, though, that even if the Seventh Amendment supported the result in Edmonson for federal civil cases, it probably would not support that result in state civil cases, because the Seventh Amendment's jury trial guarantee is among the provisions of the first eight amendments that have not been incorporated through the Fourteenth Amendment to apply to the states. See Curtis v. Loether, 415 U.S. 189, 192 n.6 (1974) (holding that jury trial in civil cases is not privilege or immunity of national citizenship which states are forbidden by Fourteenth Amendment to abridge); Walker v. Sauvinet, 92 U.S. 90, 92 (1875) (same); see also Minneapolis \& St. Louis R.R. Co. v. Bombolis, 241 U.S. 211, 217 (1916) (holding that Seventh Amendment jury trial guarantee does not apply in state court civil cases).

317. See Bush v. Vera, 116 S. Ct. 1941, 2001 n.5 (1996) (Souter, J., joined by Ginsburg \& Breyer. JJ., dissenting).

318. Id. (Souter, J., joined by Ginsburg \& Breyer, JJ., dissenting).

319. Id. (Souter, J., joined by Ginsburg \& Breyer, JJ., dissenting).

320. Id. (Souter, J., joined by Ginsburg \& Breyer, JJ., dissenting).

321. Id. (Souter, J., joined by Ginsburg \& Breyer, JJ., dissenting).

322. Id. (Souter, J., joined by Ginsburg \& Breyer, JJ., dissenting).

323. Id. (Souter, J., joined by Ginsburg \& Breyer, JJ.. dissenting). 


\section{CONCLUSION}

This Article has traced a path through the inconsistencies in the positions of the Court's champions and critics of Batson. At the beginning of the path was a question: How does race or gender discrimination in the selection of petit jurors affect the fairness of trials? At the end of the path is an answer: Jury discrimination undermines the fairness of trials not by offending the Equal Protection Clause of the Fourteenth Amendment, but by abrogating the jury trial guarantee of the Sixth Amendment.

This is not to say, of course, that race and gender discrimination in jury selection do not offend any equal protection values. As Batson's proponents have made clear in their cases extending the Batson norm, jury discrimination causes serious stigmatic and participational harms that touch the core of the Equal Protection Clause. The trouble is that these harms do not supply a reason for reversing convictions, which is what the Batson proponents want to do. Their frequent, vague pronouncements about the faimess of trials and the appearance of fairness are entirely empty since these Justices define the Batson violation in a way that forecloses any of the harms that they describe.

It is the Justices who do not seem to want to reverse convictions for Batson error ${ }^{324}$ who provide the most compelling reason for doing so. If, as Justice Scalia asserts, jurors are not fungible, then their dismissal on account of race or gender must distort the jury's deliberations and verdicts. Jury discrimination impeaches the reliability of the verdict as a trustworthy consensus of the community on the question of the defendant's guilt or innocence. This is not an equal protection harm, ${ }^{33}$ but a harm to the twin goals of representation and reliability which are the central mission of the criminal jury guaranteed by the Sixth Amendment. It is, moreover, classic Fulminante-style "structural error": error with imperceptible yet detrimental effect on the verdict. ${ }^{326}$

In order to reach the conclusion that this Article recommends, both camps of Justices-those who champion the Barson norm and those who oppose it - will have to set aside some of their views. Batson's proponents should stop

324. See supra notes $2 / 4-43$ and accompanying text.

325. As I have explained earlier, discriminatory peremptones do offend core equal protcction values See supra Section IV.A-B. Thus I do not argue in this Aricle that Batson and its progeny were wrongly decided as a matter of equal protection law, see supra note 76 (idenufying issues involved in analyzung Batson as equal protection law), simply that the equal protection theon of Batson does not adequately account for the fair trial harm caused by the discriminatory use of peremptory challenges My proposal is intended not to replace Batson, but to coexist with it and to provide a coherent reason for automatteally reversing convictions tainted by Batson error. The reach of the Sixth Amendment theory that I propose in this Article is admittedly somewhat narrower than the current reach of Batson in all its applicaltons See supra note 316.

326. See Sullivan v. Louisiana. 508 U.S. 275. 279-82 (1993) (holding that tnal court's falure to instruct jury properly on reasonable doubt standard denied defendant's Sixth Amendment nght to jun inal and was "structural error" requiring automatic reversal). 
their shrill attacks on the theory of difference and acknowledge that race and gender are at least minimally rational predictors of perspective. Batson's opponents will have to drop their revisionist insistence that the Sixth Amendment says nothing about the representativeness of the seated petit jury; that is, the Court will have to overrule Holland v. Illinois. These developments would be welcome, as they would allow both camps of Justices to rid themselves of the inconsistencies that plague their own positions. More importantly, they would allow the whole Court to announce coherently what its factions have suggested incoherently-namely, that race and gender discrimination in the selection of petit jurors makes criminal verdicts unreliable. 